nalidad en sentido estricto coincide en su efecto limitador de la pena con el principio de culpabilidad, de manera que la pena imponible a una determinada persona ha de guardar una relación de proporcionalidad tanto con el grado de injusto como con el grado de culpabilidad individual, por lo que el legislador habrá de incluir una regulación que permita a los órganos de persecución y al Juez, adoptar en los casos concretos aquellas reacciones que se encuentren en una relación de proporcionalidad tanto con el correspondiente grado de peligrosidad como el grado de culpabilidad, de forma que no grave al afectado de una manera inexigible ${ }^{203}$.

El propio Tribunal Constitucional alemán nos apunta las posibilidades que posee el legislador para respetar el principio de proporcionalidad en sentido estricto en los supuestos de injusto y culpabilidad insignificante: una solución jurídico-material y una solución formal. En virtud de la primera de ellas, el legislador puede, a través de tipos privilegiados, reducir el ámbito de aplicación de los preceptos penales o bien posibilitar la imposición de sanciones especiales para los casos de criminalidad de bagatela. La solución procesal, que es la que ha adoptado el legislador alemán en la Ley Procesal Penal, consiste en reducir o relajar las necesidades de persecución penal ${ }^{204}$. En conclusión, el principio de proporcionalidad en sentido estricto y el principio de culpabilidad, exigen que siempre que el legislador considere idóneo y necesario para la protección de un bien jurídico amenazar con pena de una forma indiscriminada todos aquellos comportamientos generalmente peligrosos para el mismo, sin privilegiar los escasamente peligrosos, habrá de incluir las previsiones necesarias que permitan encontrar la pena que se encuentre en una relación proporcional tanto con el grado de injusto como con el de culpabilidad individual del autor. $Y$ así ha procedido finalmente el legislador español en relación con el tipo básico de tráfico de drogas previsto en el art. $368 \mathrm{CP}$ tras la reforma sufrida por éste a través de la LO 5/2010. A través de ésta reforma además de reducir el límite máximo a imponer por delito de tráfico de drogas de los que causan grave daño a la salud (de 9 a 6 años), se ha previsto la facultad de reducir la pena de prisión para los supuestos de escasa entidad, facilitándose de este modo que puedan aplicar alternativas a la pena de prisión, como la suspensión o la sustitución. El párrafo $2 .^{\circ}$ del art. $368 \mathrm{CP}$ reza así: "No

203 Cfr. GRASSHOF, BVerfGE 90, 145 (203); BVerfGE 50, 205 (213 y ss.); 54, 100 (109 y ss.). Sobre la armonización de los delitos de peligro abstractoy el principio de proprocionalidad en sentido estricto vid. vid. AGUADO CORREA, El principio constitucional..., cit., pp. 337 a 390, donde se analizan las soluciones que se podrían prever en la ley en orden a esta armonización, centrándonos en las soluciones formal y material a las que se refiere el BVerfG.

204 BVerfGE 90, 145 (191). Esta opción, tal y como aclara el alto Tribunal alemán, no puede ser tachada de inconstitucional al no contravenir ningún principio constitucional, concretamente, el principio de legalidad penal contemplado en el artículo 103.2 GG, de manera que la prohibición de retroactividad de leyes penales más graves, la necesidad de previsión legal de la punibilidad, así como la determinación de la ley, no se ven afectadas por la misma. 
obstante lo dispuesto en el párrafo anterior, los tribunales podrán imponer la pena inferior en grado a las señaladas en atención a la escasa entidad del hecho y a las circunstancias personales del culpable. No se podrá hacer uso de esta facultad si concurriere alguna de las circunstancias a que se hace referencia en los artículos 369 bis y $370 "$. A través de esta previsión, el legislador ha refrendado la práctica judicial plasmada en el Acuerdo del Pleno no Jurisdiccional de la Sala 2. ${ }^{a}$ del Tribunal Supremo, de 25 de octubre de 2005.

\section{Control constitucional del respeto del principio de proporcionalidad en sentido estricto}

El control que puede llevar a cabo el Tribunal Constitucional en aquellos casos en los que el legislador no ha tenido en cuenta las exigencias del principio de proporcionalidad es más intenso que el control que puede realizar en relación con el principio de idoneidad y de necesidad. Por este motivo, el Alto Tribunal podrá declarar inconstitucional todos aquellos preceptos en los que, habiéndose acudido a la técnica de los delitos de peligro abstracto, el legislador no ha tenido presente «la razonable exigibilidad de una conducta y la proporcionalidad en caso de incumplimiento... (STC 53/1989, FJ 9)». Siempre que la imposición de la pena suponga un sacrificio innecesario y excesivo del derecho a la libertad reconocido en el artículo $17 \mathrm{CE}$, se podrá apreciar la vulneración del principio de proporcionalidad en sentido estricto. Por lo tanto, se podrán declarar contrarios a este principio todos aquellos preceptos en los cuales no se contemplan las previsiones necesarias para adecuar la pena al contenido de injusto y de culpabilidad individual. Prueba de ello es que, en la Sentencia 136/1999, de 26 de abril, el Tribunal Constitucional español declaró, por primera y única vez, la inconstitucionalidad de un precepto penal que contenía un delito de peligro abstracto, por infringir el principio de proporcionalidad en sentido estricto, en concreto, la proporcionalidad abstracta, fallando: «El precepto resulta, en efecto, inconstitucional únicamente en la medida en que no incorpora previsión alguna que hubiera permitido atemperar la sanción penal a la entidad de actos de colaboración con banda armada que, si bien pueden en ocasiones ser de escasa trascendencia en atención al bien jurídico protegido, no por ello deben quedar impunes. Expresado en otros términos, no es la apertura de la conducta típica de colaboración con banda armada la que resulta constitucionalmente objetable, sino la ausencia en el precepto de la correspondiente previsión que hubiera permitido al juzgador, en casos como el presente, imponer una pena inferior a la de prisión mayor en su grado mínimo» (FJ 30). 


\title{
Risco, «inimigo» e o direito penal do futuro ${ }^{1}$
}

\author{
HERMÍNIO CARLOS SILVA RODRIGUES
}

hcsrod@gmail.com

GALILEU - REVISTA DE DIREITO E ECONOMIA * e-ISSN 2184-1845

Volume XX $-1^{\text {st }}$ July Julho $-31^{\mathrm{TH}}$ December Dezembro $2019 \cdot$ pp. 151-195

DOI: http://doi.org/10.26619/2184-1845.XX.2.7

Submitted on October $22^{\text {th }}, 2019 \cdot$ Accepted on November $15^{\text {th }}, 2019$

Submetido em 22 de Outubro, 2019 . Aceite a 15 de Novembro, 2019

RESUMO No contexto da sociedade pós-industrial e pós-moderna em que vivemos, colocam-se novos desafios ao direito penal. O emergir de novos e grandes riscos capazes de ameaçar a estabilidade e a paz das sociedades ao nível global, a criminalidade global e altamente organizada que, em densas e complexas redes se introduz em todos os sectores da sociedade, bem como o sentimento de falência dos sistemas e das instituições para o controlo eficaz das consequências de tais fenómenos, criaram nas pessoas a sensação de insegurança e descrença nesta era do «pós».

Resultado deste sentimento global de insegurança que as transformações sociais do princípio do milénio e o emergir do terrorismo como nova ameaça global trouxeram, ocorre o movimento de «fuga para o direito penal». Os estados recorrem cada vez mais ao direito penal no sentido de controlar o risco e criar percepção de segurança nas populações, ultrapassando, muitas das vezes, os próprios limites da sua função de protecção exclusiva de bens jurídicos. O direito penal aparece cada vez mais funcionalizado a programas de política criminal securitária, cujo escopo principal é o de garantir a segurança e a paz social, recorrendo a soluções de antecipação da tutela penal, tendo com finalidade primária a integridade do sistema. Estas estratégias político-criminais estimularam doutrinas que propõem uma total funcionalização do direito penal às finalidades de prevenção geral integradora, elegendo como principal alvo da sua intervenção securitária todo aquele que seja conotado com grupos de risco, os suspeitos de ligações à criminalidade altamente organizada e transnacional e, principalmente, os suspeitos de actividades terroristas. Este sujeito é tratado como «inimigo» do sistema, elemento perturbador cuja perigosidade é necessário inocuizar, não só através do

1 O presente trabalho corresponde ao relatório da unidade curricular «O Direito - Da norma ao procedimento e à fase aplicativa» do Curso de Doutoramento em Direito do Departamento de Direito da Universidade Autónoma de Lisboa, sob a orientação do Prof. Doutor Manuel Monteiro Guedes Valente. Nota: o autor escreve segundo a grafia anterior à norma do acordo ortográfico. 
reforço exponencial da tutela repressiva, mas também da implementação de uma intolerável antecipação da tutela penal através de medidas de prevenção avançada.

A esta tendência deve contrapor-se um direito penal inspirado na dignidade da pessoa humana, que seja capaz de proteger os bens jurídicos fundamentais da comunidade sem sacrificar as garantias constitucionais da pessoa, património imaterial herdado do racionalismo humanista: é preciso (re)construir um direito penal de liberdade.

PALAVRAs-chave Pós-modernidade; risco; inimigo; segurança; liberdade; justiça

ABSTRACT In the context of the postindustrial and postmodern society in which we live, new challenges to criminal law arise. The emergence of new and great risks that threaten the stability and peace of societies at the global level, the global and highly organized crime which, in dense and complex networks, is introduced in all sectors of society, as well as the feeling that systems and institutions are failing to effectively control the consequences of such phenomena have created a sense of insecurity and disbelief in this post-post age. As a result of this global sense of insecurity that the social transformations of the early years of this millennium and the emergence of terrorism as a new global threat have brought about, there is a actual movement towards criminal law. States are increasingly resorting to criminal law to control risk and create perceptions of security among populations, often exceeding the limits of their role of exclusive protection of fundamental rights.

Criminal law appears increasingly functionalized to security policy programs, whose main scope is to ensure social tranquility and peace, using solutions to anticipate criminal protection, with the primary purpose of the integrity of the system. These strategies have stimulated doctrines that propose a full functionalization of criminal law for the purposes of integrative general prevention, choosing as the main target of their security intervention those who are connoted with risk groups, the suspects of links to highly organized and transnational crime, and especially those suspected of terrorist activities. This subject is treated as an «enemy» of the system, a disturbing element that must be controlled not only through the exponential reinforcement of repressive protection, but also through the implementation of an intolerable anticipation of criminal protection through advanced prevention measures.

This tendency must be countered by a criminal law based on the dignity of the human being, which is capable of protecting the fundamental legal assets of the community without sacrificing the constitutional guarantees, which are an intangible heritage inherited from humanist rationalism. It's mandatory that we rebuild a criminal law on the foundations of liberty itself.

KEY-WORDS Post-modernity; risk; enemy; security; liberty; justice. 


\section{Globalização, pós-modernidade e risco}

Tem sido frequente, na esteira de BECK, qualificar a sociedade pós-industrial ${ }^{2}$ como uma «sociedade de risco». ${ }^{3}$ Este novo paradigma societário emergente da pós-modernidade é marcado pela globalização, pela integração supranacional ${ }^{4}$, pela imprevisibilidade dos acontecimentos, pelo predomínio do económico sobre o político ${ }^{5}$, pelo incremento da criminalidade organizada ${ }^{6}$ e transnacional ${ }^{7}$, pelo descrédito nas instâncias de protecção e por uma maior relevância do crime macrossocial ${ }^{8}$, o que faz surgir sentimentos de insegurança. $\mathrm{O}$ desenvolvimento desmedido, norteado pela busca incessante do progresso e orientado por uma «racionalidade calculadora e instrumental», conduziu à crescente tecnificação, cientificação, economização, burocratização e juridificação do mundo e faz surgir uma nova espécie de riscos: os chamados «grandes e novos riscos»", aqueles que ameaçam as sociedades pós-industriais e cuja verificação não pode ser antecipada pela razão calculadora de riscos, nem travada nos seus «macro-efeitos» pelas técnicas actuais. Surge a percepção de que, afinal, a tecnociência pode conduzir a uma destruição incontrolável. ${ }^{10} E$ a descrença das sociedades actuais na racionalidade instrumental em falência" ${ }^{11}$ o que provoca o temor generalizado em torno dos eventos imprevisíveis.

O novo paradigma ${ }^{12}$ talhado por $\mathrm{BECK}^{13}$, chama a atenção, precisamente, para o lado mais pernicioso do desenfreado desenvolvimento da técnica (aquilo a que expressivamente

2 Cfr. Domenico de MASI, A Sociedade Pós-Industrial, 3. ${ }^{\text {a }}$ ed., Senac, São Paulo, 200o, pp. 11 e ss.

3 Cfr. Ulrich BECK, La Sociedade del Riesgo. Hacia una Nueva Modernidad, Paidós, 1998, passim, apud Hermínio RODRIGUES, Responsabilidade Penal de Pessoas Colectivas: Uma Revisitação à Luz da Teoria do Risco. Lisboa: Universidade Autónoma de Lisboa, 2016, 122 p. Dissertação de Mestrado (polic.). Vide, tb., Ulrich BECK. La Sociedad Del Riesgo Mundial: En busca de la seguridad perdida, Paidós, Barcelona, 2008; Ulrich BECK. La Sociedad Del Riesgo Global, Siglo XXI de España Madrid, 2002.

4 Cfr. Francisco LUCAS PIRES, Introdução ao Direito Constitucional Europeu, Almedina, Coimbra, 1997, pp. 11 e ss. Vide, ainda, Augusto SILVA DIAS, Protecção Jurídico-Penal dos Interesses dos Consumidores, $3 \cdot{ }^{\mathrm{a}}$ ed. polic, FDUC - IDPEE, Coimbra, 2001.

5 José Manuel PUREZA, O Património Comum da Humanidade - Rumo a um Direito Internacional da Solidariedade, Afrontamento, Lisboa, 1998, p. 17.

6 Cfr. A. SILVA FRANCO, Globalização e Criminalidade dos Poderosos, RPCC, Ano 10 - Fasc. 2. ${ }^{\circ}$, Abril - Junho de 2000 , pp. 217 e ss.

7 Cfr. FARIA COSTA, O Fenómeno da Globalização e o Direito Penal Económico, BFDUC, Studia Ivridica, n. ${ }^{\circ}$ 61, Outubro de 2001, Coimbra, Coimbra Editora, 2001, pp. 540 e ss.

8 Cfr. Mário FERREIRA MONTE, O Futuro tem Direito Penal? O Direito Penal tem futuro? Apontamento introdutório à obra de Paulo S. FERNANDES, Globalização, "Sociedade de Risco" e o Futuro do Direito Penal, Almedina, Coimbra, 2001.

9 Ulrich BECK, ibidem. Cfr. Hermínio RODRIGUES, op. cit., p. 16.

10 Cfr. Federico STELLA, Giustizia e Modernitá. La Protezione dell' Inoccente e la Tutela delle Vittime, Giuffre Editore, Milano, 2002, prefácio, p. 7. Cfr. Hermínio RODRIGUES, op. cit., p. 17.

11 Cfr. Alain TOURAINE, Crítica da Modernidade, Piaget, Lisboa, 1994, p. 220.

12 Cfr. Rodrigo CARDOZO POZO (Bases de La Política Criminal e Protección Penal de la Seguridad Vial, Universidad de Salamanca, 2009, 509 f., Tese de Doutoramento, p. 106): "Esa sociedad del riesgo, cuya denominación a partir de la obra de BECK alcanzó el carácter de «paradigma» y, por lo mismo, una nueva plataforma para ver y comprender la sociedad.". Cfr. Hermínio RODRIGUES, op. cit., p. 17.

13 Ulrich BECK, Op. cit., p. 46. Cfr. Hermínio RODRIGUES, op. cit., p. 17. 
chama "o lado obscuro do progresso"), com a consequente falácia do seu sistema de cálculo de riscos, o que implica consequências negativas susceptíveis de fazer perigar a continuidade da própria sociedade, enquanto estrutura organizatória da convivência entre os humanos. As sociedades modernas confrontam-se com os fundamentos e limites do seu próprio modelo e, ao mesmo tempo que conservam as suas estruturas, não reflectem sobre os seus efeitos. É a dimensão esmagadora dos efeitos secundários de longo prazo que faz com que a sociedade pós-industrial tome consciência dos grandes riscos promovidos pela sua racionalidade fundante e se transforme em uma «sociedade do risco», num processo a que BECK chama de "modernização reflexiva"14.

A "sociedade do risco" é uma sociedade catastrófica, o que requer uma constante reorganização do poder e da responsabilidade, pois que os estados de excepção tendem a converter-se em estados de normalidade. A sociedade da informação potencia uma percepção generalizada de insegurança ao amplificar fenómenos como o terrorismo internacional e os acidentes tecnológicos, o que os torna especialmente vívidos na mente do cidadão, o qual, deste modo, interioriza a noção de risco permanente, experimentando a incerteza, a antecipação dos acontecimentos. O cidadão vive o real ainda não acontecido, pela noção que tem da iminência dos fenómenos. ${ }^{15}$

Esta «sociedade do risco» traz um dado novo: a diferenciação entre risco e perigo, noções não inteiramente coincidentes. A potenciação dos novos riscos decorre sempre de decisões humanas ${ }^{16}$, podendo perspectivar-se como auto-agressões da sociedade sobre si mesma. Já os perigos, enquanto dramas humanos, não resultam de decisões baseadas em critérios de oportunidade técnico-económica. Conforme aponta LUHMANN ${ }^{17}$, vivemos actualmente em um contexto societário no qual se perspectiva o futuro com base numa lógica do «risco das decisões». E este problema pode tornar-se exponencial à medida que mais decisões são tomadas em cadeia, como consequência umas das outras. O risco torna-se não só global, como transgeracional. ${ }^{18}$

A globalização trouxe progressos à humanidade. No entanto, tal aproximação de povos e culturas num grande espaço de contacto e miscigenação a todos os níveis, trouxe, também, riscos desconhecidos e, consequentemente, as sociedades tendem para a incerteza, a

14 Ulrich BECK, D’Une Théorie Critique de la Société, p. 338 e ss., apud SILVA DIAS, Op. cit., p. 4. Cfr. Hermínio RODRIGUES, op. cit., p. 18.

15 Cfr. Ulrich BECK, La Sociedad del Riesgo..., cit. pp. 39 e ss.

$16 \mathrm{Cfr}$. Susana AIRES DE SOUSA, Risco, precaução e responsabilidade no horizonte da incerteza, in: Estudos em Homenagem ao Professor Doutor José Joaquim Gomes Canotilho, BFD, Stvdia Juridica n. ${ }^{\circ}$ 102, Coimbra Editora, Coimbra, 2012 , p. 685. Cfr. Hermínio RODRIGUES, op. cit., p. 19.

17 Niklas LUHMANN, Risk: A Sociological Theory, Walter De Gruyter, Berlin-New York, 1993, p. 23. Cfr. Hermínio RODRIGUES, op. cit.. p. 19.

18 Cfr. François OST, O Tempo do Direito, Piaget, Lisboa, 2001, p. 345. 
insegurança e a instabilidade. GIDDENS considera que a globalização gerou uma sociedade global marcada pela "intersecção da presença e da ausência"19 e caracterizada pelo "entrelaçamento de eventos sociais e relações sociais que estão à distância de contextos locais"20 $\mathrm{O}$ efeito «globalização» acarreta, então, outro elemento decisivo para a incontrolabilidade dos novos riscos: a sua ubiquidade e a dos seus factores potenciadores. ${ }^{21}$ Hoje, ao contrário dos primeiros tempos do progresso da tecnociência nas sociedades pré-industrial e industrial, os riscos não são delimitáveis a um espaço e a um tempo, "os seus efeitos expandem-se por extensões consideráveis do planeta, arrastam-se por períodos mais ou menos longos e impossibilitam a determinação do círculo dos afectados"22. A este respeito, refere-se BECK ${ }^{23}$ ao fenómeno que designa por «efeito boomerang», processo através do qual agentes do crime e vítimas do mesmo se confundem pela indeterminação do espaço em que os efeitos nocivos se fazem sentir e pela absoluta imprevisibilidade do número de pessoas que poderão afectar. ${ }^{24}$ Diz-nos FIGUEIREDO DIAS ${ }^{25}$ que este fenómeno é próprio da transição da sociedade industrial para uma sociedade tecnológica global, onde a massificação das acções humanas é capaz de produzir riscos globais. Este quadro coloca em crise o paradigma do direito penal liberal, pensado para a sociedade industrial no contexto da qual os riscos para os bens jurídicos essenciais à vida em comunidade provinham de acções humanas individuais, com actores bem definidos, para a contenção dos quais eram suficientes os bens jurídicos individuais e a dogmática tradicional, pensada para as formas individuais do agir e para uma criminalidade de contexto local.

A sociedade de hoje convive com uma criminalidade estrutural, estruturada e global. A globalização económica, política, tecnológica e cultural ${ }^{26}$ alargou os horizontes da crimina$\operatorname{lidade}^{27}$, a qual, aproveitando ao máximo os novos espaços de actuação, as novas tecnologias

19 Anthony GIDDENS, As Consequências da Modernidade, Celta, Lisboa, 1992, p. 27. Cfr. Hermínio RODRIGUES, op. cit., p. 17.

20 Idem, ibidem.

21 Cfr. Daniel INNERARITY, A Sociedade Invisivel, Teorema, Lisboa, 2009, p. 9; Hermínio RODRIGUES, op. cit.

22 Augusto SILVA DIAS, Op. cit., p. 4. Cfr. Hermínio RODRIGUES, op. cit., p. 20.

23 Ulrich BECK, apud Augusto SILVA DIAS, ibidem. Cfr. Hermínio RODRIGUES, ibidem.

24 Realidade esta que contrasta com aqueloutra descrita por DUPUY (apud José Manuel PUREZA, Op. cit., p. 25): "Vasto mundo, rico em países longínquos, vivendo na feliz ignorância uns do outros". Cfr. Hermínio RODRIGUES, op. cit., p. 20.

25 Jorge de FIGUEIREDO DIAS, Direito Penal, Parte Geral - Tomo I, Coimbra Editora, Coimbra, 2004, pp. 127 e ss. Vide, tb. Jorge de FIGUEIREDO DIAS, o Direito Penal entre a "Sociedade industrial" e a "Sociedade do Risco", in: Estudos em Homenagem ao Prof. Doutor Rogério Soares, BFDUC, Stvdia Ivridica, n. ${ }^{\circ} 61$, Outubro de 2001, p. 583 e ss.

26 Cfr. Anthony GIDDENS, O Mundo na Era da Globalização, Editorial Presença, 200o, p. 22 e ss.

27 Sobre a relação entre globalização e criminalidade global, vide DIAS DUARTE, Branqueamento de Capitais. O Regime do D.L. 15/93 de 22 de Janeiro e a Normativa Internacional, Porto, Universidade Católica, 2002, p. 17. Céptico (estamos em crer) acerca desta relação está PRITTWITZ. Cfr. Cornelius PRITTWITZ. Sociedad del Riesgo y Derecho Penal, in: ARROYO ZAPATERO / NEUMANN / NIETO MARTÍN, Crítica y justificación del Derecho penal en el cambio de siglo. El análisis crítico de la Escuela de Frankfurt, Universidad de Castilla-La Mancha, Cuenca, 2003, p. 149. 
e as novas dinâmicas de organização social ${ }^{28}$ resultantes do recuo da influência dos Estados no tecido social internacionalizou-se, integrou-se socialmente ${ }^{29}$ e organizou-se, assumindo características alheias à ideia de delinquência como fenómeno marginal. Afirma, a propósito, Anabela MIRANDA RODRIGUES: "a nova criminalidade é expressão deste novo modelo de organização social para que tendem as sociedades contemporâneas" ${ }^{30}$, ou seja, um modelo de sociedade polarizada em múltiplas redes, que a tornam multiforme e policêntrica.

A criminalidade deixou de estar à margem da sociedade para fazer parte dela, de modo que, hoje pode dizer-se que existe uma simbiose entre sociedade e crime, já que a criminalidade está infiltrada nos centros de decisão políticos, económicos e financeiros e processa-se em complexas redes criminosas, as quais aproveitam as estruturas e instituições sociais, confundindo-se com elas ${ }^{31}$. Há como que uma porosidade entre a sociedade oficial e a sociedade do crime $^{32}$, aumentando exponencialmente a dificuldade da detecção e, inclusive, a percepção da actividade criminosa. ${ }^{33}$

Por outro lado, o recuo do Estado Social ${ }^{34}$ expôs as sociedades a mecanismos de autorregulação dos mercados e à desinstitucionalização dos procedimentos. Isto gera incerteza e receio como reacção aos novos fenómenos globais como o terrorismo e a criminalidade grave e altamente organizada, aquilo que Hans JONAS chamou de «heurística do medo» ${ }^{35}$ Este novo paradigma sociológico possibilita o surgimento de totalitarismos, novos leviatãs que, através de discursos populistas, pretendem instituir regimes jurídicos funcionalizados a gerar percepção de segurança nas populações ${ }^{36}$, fazendo variar as suas políticas de segurança entre "os extremos da «segurança da normalidade» e a «segurança da excepção». ${ }^{37}$

28 Cfr. Anabela MIRANDA RODRIGUES, Criminalidade Organizada - Que Política Criminal?, in: Direito Penal Económico e Europeu - Textos Doutrinários, III vol., IDPEE, Coimbra Editora, Coimbra, 2009, p. 187.

29 Jean DE MAILLARD, Crimes e Leis, Piaget, Lisboa, 1995, pp. 94.

30 Anabela MIRANDA RODRIGUES, ibidem. Cfr. Hermínio RODRIGUES, op. cit., p. 60.

31 É, no fundo, a «sociedade fractal» de que nos fala Jean de MAILLARD. Cfr. Jean de MAILLARD, L'Avenir du Crime, Flammarion, 1997, pp. 43 e ss., apud, Anabela Miranda RODRIGUES, Criminalidade Organizada..., cit., 185.

32 Cfr. Jean DE MAILLARD, Crimes e Leis, cit., p. 91.

33 Cfr. Anabela MIRANDA RODRIGUES, Politica Criminal - Novos Desafios, Velhos Rumos, in: Liber Discipulorum para Figueiredo Dias, Coimbra Editora, Coimbra, 2003, p. 207; Vitalino CANAS (O Crime de Branqueamento de Capitais - Regime de Prevenção e Repressão, Almedina, Coimbra, 2004, p. 10; Hans SCHNEIDER, Recientes investigaciones criminológicas sobre la criminalidad organizada", in: Revista de Derecho Penal y Criminologia, 3, 1993, p. 723.

34 Cfr. François OST, O Tempo do Direito, Piaget, Lisboa, 2001, p. 337. Sobre os efeitos da globalização sobre a própria noção de Estado na pós-modernidade, cfr. J. Peter ANDERSON, Política Global do Poder, Justiça e Morte, Piaget, Lisboa, 1998, pp. 103 e ss.

35 Cfr. Idem, ibidem. Quanto à teoria de JONAS, vide Hans JONAS, El principio de responsabilidad: ensayo de una ética para la civilización tecnológica, Herder, Barcelona, 1995, p. 29 e ss.

36 Cfr. François OST, O Tempo do Direito, Piaget, Lisboa, 2001, pp. 342-343.

37 Jorge BACELAR GOUVEIA, Direito da Segurança, Almedina, Coimbra, 2018, p. 54. 
Assim, em contraste com o fraco intervencionismo social do direito penal liberal do iluminismo, a pós-modernidade é marcada por uma tendência de sobrepenalização, no contexto de um incremento do recurso ao Direito em geral, como fenómeno de regulação, no sentido de restituir uma certa orientação às sociedades carentes de referentes. É o ordo-liberalismo posto em prática. No entanto, esta juridificação cada vez maior de todo o quotidiano, torna o próprio Direito numa ameaça mais presente do que a própria protecção que confere, o que é fortemente acentuado pela crescente instabilidade legislativa fruto de uma certa precarização do Direito e dos seus princípios. As sociedades pós-modernas reagem à ameaça dos grandes e novos riscos com nervosismo e intranquilidade, o que tem causado um alargamento da responsabilidade jurídica em geral e penal em particular. No que tange à responsabilidade penal, a percepção do risco social instala uma crise sistémica: se, por um lado, se afirma que a protecção e recuperação do tecido social é, ainda, tarefa do direito penal, por outro afirma-se a inépcia dos seus princípios liberais.

É, assim, que, na resposta penal aos novos desafios da sociedade pós-moderna, vão pontuar duas grandes tendências: a expansão do direito penal, marcada pela sua desformalização e funcionalização exacerbada, elegendo como bem jurídico supremo a segurança cognitiva e atingindo o seu auge no "direito penal do inimigo"; por outro lado, a reafirmação de um direito penal mínimo, orientado para a protecção exclusiva, subsidiária e fragmentária de bens jurídicos, favorecendo a culpa como critério de imputação subjectiva e a liberdade como critério processual reitor.

A intervenção jurídico-penal do Estado Moderno passa, então, por duas fases: a invenção do Estado pela necessidade do estabelecimento da paz pública; a afirmação dos direitos e das liberdades dos indivíduos em face do Estado omnipotente; No Estado Pós-Moderno surge o valor da segurança colectiva como contraponto do exercício das liberdades individuais. Nesta sede, o grande problema da actualidade está em estabelecer a simbiose vital entre liberdade e segurança, para que os termos do binómio não se anulem mutuamente.

Iluminismo absolutista, garantismo humanista e funcionalismo securitário: da repressão à liberdade; do direito penal mínimo à ilusão de segurança e à crise do humanismo penal

\section{As origens remotas do «direito penal do inimigo»}

A ideia de que a justiça não é necessariamente igualitária e que depende do próprio posicionamento do indivíduo face ao todo social e do modo como este integra, ou não, aquele, não é nova, muito menos recente. A ideia de que a integridade do sistema jurídico, social e político depende do controlo do risco e da insegurança e que isso exige a sujeição 
dos indivíduos à lei e à justiça, bem como o extirpar dos elementos que não se submetem à legalidade, pode divisar-se já na antiguidade clássica. Os delinquentes que, depois de sofrerem o efeito preventivo e dissuasor das penas, ainda assim não partilhassem dos valores comummente aceites na polis deveriam ser dela apartados e tratados no âmbito de um sistema diferenciado de justiça, marcado por uma supressão da sua dimensão de cidadão e tratado como um «inimigo». A génese do «direito penal do inimigo» pode, então, encontrar-se nas concepções político-jurídicas da escola sofista, de pendor fortemente positivista e utilitarista. ${ }^{3}$

Também na filosofia cristã da idade média, através da doutrina de S. Tomás de Aquino, fortemente influenciado pelo pensamento de Aristóteles, se pode divisar a ideia do criminoso como «inimigo» da comunidade, objecto da acção do Estado e da justiça. Vendo no crime um pecado, S. Tomás de Aquino, não é, no entanto, tão radical como S. Agostinho, que via a natureza humana como naturalmente pecadora. A interpretação tomista é a de que o pecado é um desvio susceptível de correcção e arrependimento. O Homem pode reconciliar-se com Deus através da expiação do mal..$^{39}$ Sendo a justiça terrena uma prerrogativa do Estado, compete a este conduzir e refrear as condutas humanas através da imposição coerciva da lei, no sentido de compelir os indivíduos a agir segundo os valores da justiça, característica dos homens virtuosos. A proscrição do indivíduo face à sociedade seria, pois, necessária, quando este não se pautasse por aqueles valores e prejudicasse, assim, o bem comum. De qualquer modo, a noção de que o criminoso deve ser aniquilado pela sua iniquidade, não implica o seu tratamento desigual face ao homem justo. Em boa razão, o pensamento tomista não pode justificar qualquer funcionalismo penal tendente ao tratamento desigual do criminoso, extinguindo-lhe direitos, até porque, na filosofia tomista, o homem é um ser naturalmente sociável, sendo a sociedade política um factor conatural à natureza humana. ${ }^{40}$

\section{Iluminismo absolutista: o criminoso como inimigo do Estado}

38 Cfr. Luís CABRAL DE MONCADA, Filosofia do Direito e do Estado, Vol. I, Coimbra Editora, Coimbra, 2. ${ }^{\text {a }}$ ed., 1955, p. 14; Luís GRACIA MARTÍN, El Horizonte del Finalismo..., cit., pp. 94 e ss. Manuel M. GUEDES VALENTE, Direito

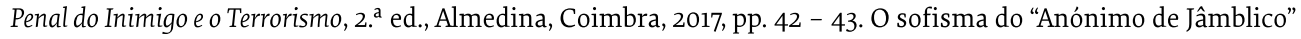
é, justamente, expressão desta idiossincrasia.

39 Cfr. Luís CABRAL DE MONCADA, Filosofia do Direito e do Estado..., cit., pp. 76 - 77; Manuel M. GUEDES VALENTE, Direito Penal do Inimigo e o Terrorismo..., cit., pp. 44 e 45.

40 Cfr. J. J. CHEVALIER; Y. GUGHET, As Grandes Obras Politicas de Maquiavel à Actualidade, Europa-América, Lisboa, 2004, p. 63. 
Foi a filosofia penal moderna que trouxe o conceito de «inimigo» para a teoria penal. Durante os sécs. XVIII e XIX fizeram curso teorias penais baseadas no contratualismo ${ }^{41}$, segundo as quais o indivíduo, ao violar as normas jurídicas, estaria a violar o contrato que firmou com os demais cidadãos, pelo que haveria de ser intervencionado de modo a reentrar no âmbito do pacto. Numa dimensão ética e política, o indivíduo que não se rege pelo Direito não tem lugar na sociedade porque ameaça a ordem, a estabilidade e até mesmo a sobrevivência do próprio Estado. Como tal, perde as prerrogativas de cidadania, sendo-lhe aplicável um outro estatuto jurídico-político, o de «inimigo da sociedade», ao qual não se reconhecem direitos, liberdades e garantias ${ }^{42}$. Para ROUSSEAU, os delinquentes que cometem crimes graves colocam em causa o contrato social como ordem política oposta à sociedade civil desigual, emergente dos movimentos sociais da modernidade. O contrato social é um compromisso político agregador e socialmente fundante de uma igualdade efectiva entre os homens. Como tal devem ser considerados inimigos e, nessa condição, subtraídos à cidadania. ${ }^{43}$ Para ROUSSEAU, o cidadão é aquele homem que, usando da sua razão natural, enforma uma sociedade votada ao bem comum ${ }^{44}$. Se não podem ser considerados cidadãos, são elementos nocivos, que devem, pura e simplesmente, ser obliterados.

A proto-teoria do «direito penal do inimigo» de JAKOBS podemos encontrá-la na diferenciação entre cidadão e inimigo defendida por HOBBES. Este jusfilósofo, precursor do absolutismo, distingue entre dois estados do indivíduo: o estado legal, em que ele se torna cidadão, e o estado de natureza, no qual o indivíduo não se pauta por imperativos éticos, jurídicos e políticos de convivência social. Como tal, o estatuto político-jurídico a dispensar aos dois estados é, necessariamente, diferenciado: ao estado legal corresponde o estatuto de cidadão; ao estado-natureza corresponde o estatuto de inimigo. ${ }^{45} \mathrm{Na}$ sua obra Leviatã, HOBBES opera a separação entre os dois estados, defendendo a aplicação de um direito penal para o cidadão e um outro para o inimigo. Tal concepção radica na convicção de que o Homem não é um ser sociável na sua natureza, ou seja, no estado de natureza não pode conviver pacificamente nem construir uma comunidade política estável. ${ }^{46}$ É no sentido de

41 Cfr. Günter JAKOBS; Manuel CANCIO MELIÁ, Derecho Penal del Enemigo, Cuadernos Civitas, Madrid, 2003, pp. 28-29.

42 Cfr. Kai AMBOS, Derecho Penal del Enemigo, in: Derecho Penal del Enemigo, Vol. I, MELIÁ; GOMEZ-JARA DIÉZ (coord.), Edisofer, Madrid, 2006, pp. 122 e ss.

43 Cfr. Luís CABRAL DE MONCADA, Filosofia do Direito e do Estado..., cit., pp. 231 e ss.; Luís GRACIA MARTÍN, El Horizonte del Finalismo..., cit., p. 101; Manuel M. GUEDES VALENTE, Direito Penal do Inimigo e o Terrorismo..., cit., p. 47.

44 Cfr. Alain TORRAINE, Crítica da Modernidade, Piaget, Lisboa, 1994, pp. 33 e ss.

45 Cfr. Manuel M. GUEDES VALENTE, Direito Penal do Inimigo e o Terrorismo..., cit., pp. 52 e 53. Vide, tb., Arthur KAUFMANN, Filosofia do Direito, 5. ${ }^{\text {a }}$ ed., Fundação Calouste Gulbenkian, Lisboa, 2014, p. 37 e 209 e ss.

46 Cfr. Hamilton SERRA DE CARVALHO. Estado Forte - Hobbesianismo e Maquiavelismo na Ordem Político-Constitucional Global, Chiado Editora, Lisboa, 2016, pp. 51-52. 
contrariar o estado de natureza que HOBBES defende a construção de um Estado forte, de cariz absolutista ${ }^{47}$, onde o monarca é o detentor do poder legislativo e punitivo ${ }^{48}$. Um Estado agregador das legitimidades e liberdades individuais, capaz de, através de princípios racionalistas de actuação, condicionar os indivíduos ao estado legal, único garante da harmonia e estabilidade sociais. Esta transferência para o Estado de uma certa dimensão do arbítrio individual opera a substituição da incerteza e do risco beligerante decorrente do egoísmo individualista do estado de natureza, pela liberdade e segurança garantidos pela obediência à lei, forjada nos moldes do naturalismo antropológico ${ }^{49}$. Só o Estado, como contrato firmado entre os indivíduos que, por receio mútuo de aniquilação (a paixão, que não a razão), se comprometem entre si, é garante da paz, da segurança e da confiança. Sendo esta a tarefa fundamental do Estado, o poder punitivo deste só se encontra limitado na medida em que houver possibilidade de conduzir o indivíduo ao estado legal, ou seja, aplica-se, nessa hipótese, o direito penal do cidadão, cujos limites estão fixados na própria lei. Caso contrário, ao indivíduo que se revele indissociável do estado de natureza, aplica-se-lhe o direito penal do inimigo (direito penal bélico), pois que ao inimigo não se lhe aplica um castigo, mas a simples hostilidade ${ }^{50}$. Este é o ideário do Estado absoluto preconizado por HOBBES no sentido de garantir a estabilidade do "pacto social constitutivo do corpo político do Estado", o qual, por sua vez, seria o garante último do pacto de obediência às leis naturais, pilar da coexistência humana.

Destarte, como dissemos, é nas prerrogativas do Leviatã de HOBBES que JAKOBS buscou inspiração para a sua concepção funcionalista do «direito penal do inimigo», pois que, ao assumir-se que o poder punitivo do soberano só é balizado por limites legais quando recai sobre o cidadão, significa que, ao «inimigo», não são reconhecidos os mesmos direitos nem, tão pouco, as mesmas garantias penais. Mas também a filosofias de KANT e de LOCKE influenciaram fortemente a doutrina de JAKOBS. KANT contribui para a concepção do inimigo como aquele indivíduo que, por orientar a sua conduta num estado de natureza, marcado pelo conflito, o egoísmo e a confrontação, constitui uma ameaça permanente à segurança jurídica, física e cognitiva da sociedade (estado de guerra). Só num contexto em que os indivíduos vivem em estado de legal é possível afastar a ameaça e a insegurança. ${ }^{51}$ O estado legal é, portanto, o único garante de um estado de paz. Para KANT, há que instituir

47 Cfr. Luís CABRAL DE MONCADA, Filosofia do Direito e do Estado..., cit., p. 172. Alain TORRAINE, Crítica da Modernidade..., cit., p. 29.

48 Cfr. Diogo FREITAS DO AMARAL, História das Ideias Políticas, Almedina, Coimbra, 1999, p. 153.

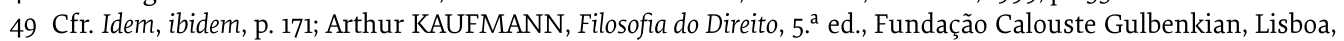
2014, p. 275.

50 Cfr. Luigi FERRAJOLI, Democracia y Garantismo, Trotta, Madrid, 2008, p. 241.

51 Cfr. Emmanuel KANT, A Paz Perpétua e outros Opúsculos, trad. Artur Mourão, Edições 70, Lisboa, 1989, pp. 126 e ss. 
o estado de paz, através da legalidade e da força normativa das leis, cuja violação determinaria que o criminoso fosse visto como se situando no estado de natureza ou, quando muito, como alguém que se desviou do estado legal. Neste último caso, o infractor seria obrigado, por aplicação de penas, a reintegrar-se no estado legal, cujos dispositivos haveria de cumprir por imperativo categórico. Todo aquele que o recusasse ou não fosse permeável aos efeitos ressocializadores, seria visto como um inimigo, alguém que nega o estado de paz, uma fonte de ameaças permanentes à ordem e à segurança pública. Aquele que se encontrasse $a b$ initio no estado de natureza, seria completamente excluído. Todavia, KANT, ao contrário de HOBBES, defendia que a pena a aplicar, no sentido da reposição do estado legal, deveria estar sujeita a critérios de pura legalidade e igualdade na aplicação de lei penal. Para KANT, o estatuto jurídico-político do inimigo não pode resultar da vontade do soberano, mas sim da tipicidade legalmente instituída.

LOCKE, embora também ele contratualista ${ }^{52}$, diverge de ROUSSEAU ao defender o individualismo como base de construção social ${ }^{53}$. Diverge, também, de KANT e de HOBBES. Para o filósofo, o homem não necessitaria de transitar para o estado legal, pois que a própria natureza humana é imbuída de preceitos jusnaturais que orientam a conduta do homem à auto-preservação e à sã convivência, embora o Homem seja dotado de livre arbítrio. A natureza humana tem, ela própria, um estado legal. Ao contrário de HOBBES, que defendia que o estado de natureza humano era um bellum omnium contra omnes ${ }^{54}$, LOCKE preconizava que o estado de natureza era um estado de liberdade individual e de igualdade, cabendo ao Estado, decorrente do contrato social, garantir o bem público e controlar as paixões exacerbadas dos indivíduos ${ }^{55}$. Para HOBBES, para quem o Estado era uma resposta ao estado de natureza, os indivíduos alienam, mediante o contrato social, a sua legitimidade e todos os seus direitos a um ente supra-individual, no sentido de este impor o estado legal e assim se atingir o estado de paz. Esta ideologia deu origem ao conceito absolutista de Estado: o estado de polícia. Já LOCKE, no que foi seguido por Rousseau, Kant, Montesquieu, Beccaria, etc., o indivíduo possui certos direitos inalienáveis, como a liberdade pessoal, para a melhor protecção dos quais aliena um pouco da sua legitimidade política em favor do Estado, sendo este uma resposta ao estado de guerra, não sendo, pois, este admissível por antitético face à natureza human $\mathrm{a}^{56}$. Os conceitos de estado de natureza e de contrato social fundam, para LOCKE, um Estado de Direito, liberal e mínimo. ${ }^{57}$ Todavia, LOCKE sabia que, mesmo no

52 Cfr. Alan TORRAINE, Crítica da Modernidade, Piaget, Lisboa, 1994, p. 68.

53 Cfr. Idem, ibidem.

54 Cfr. Idem, p. 67.

55 Luís CABRAL DE MONCADA, Filosofia do Direito e do Estado..., cit., pp. 212 e 213.

56 Cfr. Alan TORRAINE, Crítica da Modernidade..., cit., p. 67.

57 Luis CABRAL DE MONCADA, Op. cit., pp. 214 e 215. 
estado de natureza como ele o preconizava, o indivíduo poderia adoptar comportamentos de ruptura, desobedecendo às leis naturais que regem a conduta humana. Quando assim fosse, o indivíduo subtrair-se-ia, ele próprio, à comunidade e sujeitar-se-ia a ser tratado como um elemento nocivo. Aqui, a liberdade que assiste aos restantes indivíduos da comunidade para punir ou aniquilar o outsider é bastante mais ampla do que aquela que resulta da lei aplicável aos que não são inimigos da comunidade politicamente organizada, sendo estes aqueles infractores pontuais sem, contudo, se mostrarem hostis aos valores instituídos.

Um dos autores que levou mais longe a ideia do criminoso como «inimigo da sociedade» foi FICHTE, um dos precursores do idealismo alemão. Fortemente influenciando por Kant, o autor defende a objectivização total daquele que, violando gravemente um bem jurídico de grande valor social como a vida, rompe o pacto social, extingue a relação jurídica com o Estado. Partindo do exemplo do homicida, para FICHTE, o criminoso grave deve ser totalmente reificado ao ponto de ser desprovido de quaisquer direitos ${ }^{58}$. Destarte, a sua vida está à inteira disposição do Estado que o pode executar a título de medida de segurança, sendo, não obstante, tarefa do mesmo Estado, garantir que o indivíduo não atinge este estádio de anomia, através do controlo efectivo sobre o quadro comportamental. A morte do criminoso não é uma pena, conquanto este se apresente como incorrigível. É uma medida de gestão com vista à pacificação social. Contudo, FICHTE não preconiza esta solução para toda a criminalidade, sem distinção, porquanto considera que nem todos os crimes são susceptíveis de operar a ruptura da relação Estado-indivíduo-sociedade. Para os crimes de menor gravidade, propõe o autor que, através da aplicação de uma pena, se proponha a regeneração política do infractor através de um contrato de expiação.

Embora a idiossincrasia dos contratualistas tenha tido a virtualidade de lançar as bases da teleologia preventiva especial do direito penal, na verdade, a única preocupação era a integridade do sistema político e jurídico, vista, do ponto de vista sociológico, como essencial à vigência e funcionamento do contrato social.

\section{O garantismo humanista}

Em finais do séc. XVIII, o absolutismo entra em colapso e, com ele, também a ideia de que o Estado está legitimado a actuar repressivamente contra qualquer ameaça à segurança, à ordem pública e à paz jurídica. O direito penal é, agora, concebido como um direito votado

58 Cfr. Günter JAKOBS; Manuel CANCIO MELIÁ, Derecho Penal del Enemigo, Cuadernos Civitas, Madrid, 2003, pp. 28 e ss.; Germán ALLER, El Derecho Penal del Enemigo y La Sociedad de Conflicto, in: Derecho Penal del Enemigo, Vol. I, MELIÁ; GOMEZ-JARA DIÉZ (coord.), Edisofer, Madrid, 2006, p. 90 e ss.; Manuel M. GUEDES VALENTE, Direito Penal do Inimigo e o Terrorismo..., cit., pp. 48-49. 
à preservação da liberdade individual e à garantia das condições essenciais à existência do ser humano, sendo mandatado com o poder estritamente necessário para o efeito. Assim, o próprio Direito actua como forma de limitar o poder do Estado face ao indivíduo e proteger os interesses fundamentais da comunidade tornados bem jurídico-penais, garantindo, assim, a paz social, bem como o exercício dos direitos fundamentais da pessoa. ${ }^{59} \mathrm{O}$ direito penal herdeiro dos valores do racionalismo humanista é um direito penal de liberdade e de igualdade, tendo surgido como forma de reagir contra as arbitrariedades no exercício do ius puniendi, bem como contra os diferentes tratamentos baseados no status económico e social. Os valores da Revolução Francesa de 1789, corporizados na Declaração dos Direitos do Homem e do Cidadão, bem como na Constituição de 1795, foram transpostos pelo positivismo setecentista para a lei penal. É afirmado o princípio da legalidade, bem como o princípio da igualdade de todos perante a lei. É a partir do pensamento e, principalmente, da obra de BECCARIA que mais influencia a reacção contra a prepotência do Estado absoluto e contra o seu direito penal totalitário e opressivo. ${ }^{60} \mathrm{Se}$, à época, o direito penal visava a manutenção da paz jurídica e da segurança e ordem públicas, não hesitando em usar de todas as medidas de polícia que tal desiderato reclamasse, BECCARIA vem afirmar que a legitimidade de punir do Estado deriva de um pacto social, de um mandato dos cidadãos, e que o indivíduo é dotado de personalidade e dignidade humana, não podendo ser usado como meio para atingir a paz jurídica e a ordem pública. Assim, o ius puniendi apenas é legítimo nos termos desse mandato, cujo alcance é pré-fixado na lei e pelas garantias nela afirmadas, no respeito integral pela dignidade e igualdade do indivíduo perante a lei. O direito penal do iluminismo coloca no centro da discursividade penal a pessoa em situação de igualdade, sem distinções. Não há pode haver lugar a tratamentos diferenciados conforme se está «dentro do contrato» ou fora dele. O direito penal deve reger-se por um paradigma de humanidade, concretizado num sistema que respeite a dignidade da pessoa humana em igualdade ${ }^{61}$. O ideário de BECCARIA constitui, pois, o alicerce do garantismo na relação com o poder do Estado.

Gerou-se, então, a partir dessa base, um direito penal de cunho garantista, de carácter humanista, que se assume como ordem de liberdade e não de repressão. É um direito

59 Cfr. Manuel M. GUEDES VALENTE, Direito Penal do Inimigo e o Terrorismo, 2. a ed., Almedina, Coimbra, 2017, pp. 18-19 .

60 Cfr. José de FARIA COSTA, Ler Beccaria Hoje, in: Cesare BECCARIA, Dos Delitos e das Penas, Fundação Calouste Gulbenkian, Lisboa, 1998, p. 8.

61 Cfr. Jorge de FIGUEIREDO DIAS, Direito Penal - Parte Geral..., cit., pp. 35-37; Anabela MIRANDA RODRIGUES. Criminalidade Organizada - Que Política Criminal? In: Direito Penal Económico e Europeu - Textos Doutrinários, Vol. III, IDPEE, Coimbra Editora, Coimbra, 2009, p. 198. Manuel M. GUEDES VALENTE, La Política Crimina y la Criminología en Nuestros Dia. Una Visión Desde Portugal, in: Derecho Penal y Criminología como Fundamento da la Politica Criminal. Estudios en Homenaje al Prof. Alfonso Serrano Gómez, Dickinson, Madrid, 2006, pp. 1309-1318. 
mínimo, que só intervém em ultima e extrema ratio. A ordem pública, a paz jurídica e a segurança e tranquilidade são asseguradas através da protecção subsidiária dos interesses fundamentais da comunidade ${ }^{62}$, sendo as penas aplicadas à pessoa com vista à sua reconciliação social e reconstituição da integridade da norma violada ${ }^{63}$. Trata-se, pois, de um modelo penal marcada por três grandes vectores: liberdade (legalidade), carácter instrumental e subsidiário (protecção de bens jurídicos penais em ultima et extrema ratio), actuação retrospectiva, (direito penal do facto), teleologia preventiva das penas (prevenção geral e especial). No essencial, o novo direito penal garantista e humanista abandona a e proscreve a concepção nihilista do infractor como «inimigo» da ordem e da paz pública do absolutismo, para o considerar como um fim em si mesmo, estando o sistema penal sempre comprometido com a sua reintegração social. O criminoso não pode, em caso algum, ser visto como coisa, instrumentalizado por um sistema apenas comprometido com a sua própria integridade, mas sempre como um entidade dotada de direitos e deveres.

Não obstante, o espectro de um direito penal do agente, ao arrepio de um direito penal do facto, nunca desapareceu verdadeiramente. Podemos notá-lo na doutrina de VON LISZT, no que tange à distinção político-criminal e penológica entre criminosos reincidentes, delinquentes habituais e delinquentes por tendências, cuja influência é bem patente no Código Penal Português de 1886. O insigne autor defendia que infractores com estas características, considerados "inimigos fundamentais da ordem social" ${ }^{4}$, deveriam ser sujeitos a penas de duração indeterminada, como forma de controlo comportamental, o que constitui, claramente, um tratamento penológico diferenciado para uma categoria de infractores, embora se possa considerar, com GUEDES VALENTE ${ }^{65}$, que se trata, ainda assim, de uma discriminação em função da maior dificuldade de ressocialização que tais sujeitos denotam e que o fim último de tal reforço sancionatório é, ainda e sempre, a sua recuperação social e não a sua inocuização. ${ }^{66}$

Foi em pleno séc. XX que a noção de «inimigo» inspirou, como nunca antes, um sistema jurídico concreto. O nacional-socialismo do III Reich adoptou um sistema penal totalitário, absoluto e repressivo, usado como instrumento de terror, através do qual procurou eliminar todos aqueles que, por razões de ascendência geográfica, etnia, confissão religiosa ou ideologia fossem considerados inimigos do Estado, por, alegadamente, representarem para este uma ameaça à respectiva estabilidade. Obliterando por completo o princípio da

62 Cfr. José de FARIA COSTA, Ler Beccaria Hoje, cit., p. 24

63 Cfr. Manuel M. GUEDES VALENTE, Direito Penal do Inimigo e o Terrorismo, cit., pp. 70-71.

64 Luís GRACIA MARTÍN, O Horizonte do Finalismo..., cit., p. 120.

65 Cfr. Manuel M. GUEDES VALENTE, Direito Penal do Inimigo..., cit., p. 59.

66 Todavia, podemos antever no Código Penal de 1886 laivos de uma concepção de «inimigo» social nas medidas de segurança pré-delituais aplicáveis a imputáveis. 
legalidade e da tipicidade estrita de crimes e penas, o sistema penal nazi aplicava penas de forma arbitrária, desconsiderando, também, totalmente, o princípio da igualdade. Foi, assim, um claro e espectacularmente assustador exemplo de funcionalização securitária de um sistema penal. Assentando na doutrina de MEZGER, fortemente inspirado por HEIDEGGER, o direito penal do III Reich ${ }^{67}$ constitui o mais acabado exemplo de uma concretização efectiva de um «direito penal do inimigo» levado ao extremo. No seu âmbito, operou-se uma completa despersonalização do arguido, o qual é despido da sua condição humana, sendo tratado pelo Estado como simples res. Por outro lado, a experiência do Holocausto mostrou-nos como um sistema penal baseado na teoria do «inimigo» pode ser utilizado como instrumento de aniquilação, sob o manto legitimador da lei.

Consequência da experiência das duas Grandes Guerras, o cariz garantista do direito penal acentuou-se, ganhou novo fôlego na $2 .^{a}$ metade do séc. XX, na sequência da experiência adquirida nas duas Grandes Guerras. $O$ jusnaturalismo triunfou definitivamente sobre as teorias do positivismo exasperado de inspiração cartesiana e kantiana, que conduziram ao «estado de legalidade» e à coisificação da pessoa através de sistemas jurídicos totalitários comprometidos com a tutela exacerbada e absolutista ${ }^{68}$ de bens jurídicos supra-individuais e colectivos, usando o direito penal como instrumento securitário. O agente de crimes deixa de ser visto como um inimigo do sistema, um indivíduo em «estado de natureza», para ser perspectivado em toda a sua dignidade de ser humano. Isto por força de dois marcos históricos em matéria de direitos humanos e estatuto da pessoa na relação com o Estado: a Declaração Universal dos Direitos Humanos e a Convenção Europeia dos Direitos Humanos. As sociedades reagiram à tentativa de transformar o direito penal num instrumento de segurança através da submissão da cidadania ao interesse difuso da ordem social e da paz jurídica, impondo que, nos textos constitucionais, figurassem um conjunto de garantias fundamentais da pessoa contra o puder punitivo do Estado, garantias materiais e processuais inarredáveis e sujeitas a limite de revisão constitucional.

Surge, então, o direito constitucional penal (ou Constituição penal) com um alcance muito próximo do conteúdo da Declaração Universal dos Direitos Humanos. Como diz GUEDES VALENTE, "inverte-se a protecção da segurança cognitiva"69: 0 «inimigo» deixa de ser o indivíduo infractor, que constituía uma ameaça para a integridade do Estado e para a percepção de segurança da comunidade, para ser o próprio Estado o novo «inimigo», contra

67 Não é, de resto, exemplo único. Os sistemas penais dos regimes totalitários de inspiração socialista-marxista também são/eram baseados no conceito de «inimigo» do Estado e, portanto, a sociedade. Tais sistemas penais eram autênticos instrumentos de controlo político e social.

68 Tomamos a expressão de Manuel M. GUEDES VALENTE (Direito Penal do Inimigo..., cit., p. 73).

69 Manuel M. GUEDES VALENTE, Direito Penal do Inimigo..., cit., p. 73. 
cujo poder abusivo há que defender o cidadão através de um programa penal e processual penal garantista e humanista, capaz, não só de proteger os valores essenciais à subsistência social, mas também de ressocializar o infractor no estrito respeito pela sua dignidade do ser humano. "O baluarte da dignidade da pessoa humana impõe aos estados que tratem os seus membros (...) como seres humanos, depositários de direitos, liberdades e garantias penais materiais, processuais e penitenciárias." ${ }^{70}$

Através do pensamento de autores como FERRAJOLI ${ }^{71}$, começa, então, a desenvolver-se, aquilo que usa chamar-se «direito penal do cidadão», por oposição ao «direito penal do inimigo», um direito penal assente nos valores da dignidade humana e da liberdade pessoal, ordenado à protecção subsidiária e fragmentária de bens jurídicos penais e à prevenção especial positiva, posto em prática por um processo penal atribuidor de garantias processuais de ampla defesa e respeito pelos direitos fundamentais do arguido. A pena só faz sentido pela prática de um facto típico, socialmente desvalioso e censurável ao agente, dentro do quadro axiológico constitucional e dos direitos, liberdades e garantias ali consagrados. "O direito penal do cidadão exige que se olhe para o direito penal como um direito de liberdade, e para o direito processual penal como o direito, por excelência, dos inocentes."72

O funcionalismo securitário: a crise do humanismo penal

Não obstante o paradigma do «direito penal do cidadão» se tenha institucionalizado e estabilizado até ao fim do séc. XX, a verdade é que, com o fim do século, novos desafios se lhe colocam. Os «grandes e novos riscos» emergentes na sociedade pós-industrial, pós-moderna e globalizada, que BECK chamou de «sociedade do risco» ${ }^{73}$, trouxeram a incerteza e o medo à sociedade e, assim, provocam sentimentos generalizados de insegurança ${ }^{74}$. A ubiquidade e imprevisibilidade dos riscos ${ }^{75}$, a noção da falência da técnica instrumental calculadora pela complexidade e incontrolabilidade das novas fontes de perigo, como a manipulação genética, a indústria bioquímica e, principalmente, a maior visibilidade do

70 Cfr. idem, ibidem.

71 O insigne autor defende que o direito penal humanista é aquele que, não só atribui um conjunto de garantias essenciais ao indivíduo que lhe permitem defender-se contra o exercício do poder de punir do Estado, como também promove activamente a integridade a aplicação dessas garantias. Cfr. Luigi FERRAJOLI, Derecho y Razón. Teoria del Garantismo Penal, trad. de P. Ibañez et. al., 5. ${ }^{a}$ edição, Trotta, Madrid, 2005 e tb. Luigi FERRAJOLI, Democracia y Garantismo, Trotta, Madrid, 2008.

72 Manuel M. GUEDES VALENTE, Direito Penal do Inimigo..., cit., p. 74.

73 Ulrich BECK, La Sociedade del Riesgo. Hacia una Nueva Modernidad, Paidós, 1998. Vide, tb., Idem. La Sociedad Del Riesgo Mundial: En busca de la seguridad perdida, Paidós, Barcelona, 2008; Idem. La Sociedad Del Riesgo Global, Siglo XXI de España Madrid, 2002.

74 Cfr. Manuel M. GUEDES VALENTE, ibidem, p. 76; Juarez TAVARES. A Globalização e os Problemas de Segurança Pública, in: Revista da Associação Brasileira de Professores de Ciências Penais, São Paulo, ano 1, n. ${ }^{\circ}$ 00, 2004.

75 Cfr. Augusto SILVA DIAS. Protecção Jurídico-Penal dos Interesses dos Consumidores, $3 \cdot{ }^{\mathrm{a}}$ ed. polic, FDUC - IDPEE, Coimbra, 2001, p. 7. 
fenómeno do terrorismo, são factores que criam nas comunidades novas e desconhecidas sensações de perigo, impotência e pânico e, por isso, dão origem a novos estados de alerta. Podemos, então dizer que a "criminalidade e [o] medo da criminalidade marcam a contemporaneidade. ${ }^{76}$ A recente percepção dos custos da globalização e da real ameaça da criminalidade organizada, fizeram erguer a bandeira do combate cerrado a esse fenómeno, a qual tem servido de argumento de marketing político, incutindo na sociedade a ideia de que o garantismo é um obstáculo à eficácia desse combate e de que vale a pena sacrificar certas garantias para, assim, afirmar a segurança e a tranquilidade públicas ${ }^{77}$. Deste modo, a política criminal tende a transformar-se numa política de «segurança». Não obstante, as cada vez mais complexas e organizadas redes de criminalidade transnacional tornam exponencialmente mais difícil a descoberta do ilícito e dos seus agentes. A danosidade social deste tipo de criminalidade é elevada, principalmente tendo em conta que se entrecruza com o poder económico e político, o que gera ainda desconfiança e descrença no aparelho de Estado, na bondade das leis e, muito particularmente, no poder judicial, cuja acção é, para muitos, cerceada pelo excessivo garantismo do processo penal.

A pós-modernidade, que BAUMAN expressivamente apelidou de "modernidade líquida"78, é um tempo de perda de referentes, de integração, fusão e erosão cultural no plano do imediatismo. Uma sociedade de consumo acrítica, voltada para o edonismo e sem objectivos reais. Uma sociedade que perdeu a utopia e não projecta o futuro. Uma sociedade dominada pelos mercados, pelas estatísticas e índices, marcada por uma forte desregulamentação fruto do recuo do Estado Social. Esta realidade cria no indivíduo uma forte percepção de incerteza e insegurança, pela mutabilidade constante dos referentes. FARIA COSTA chama a atenção para a actual crise da ética, do direito penal e da percepção da realidade, a qual convive com a uma aceitação do "absolutismo do global"79.

A confiança num direito penal liberal, subsidiário, mínimo e fragmentário para o combate eficaz à nova criminogénese é cada vez mais abalada ${ }^{80}$, o que tem aberto novos espaços a discursos populistas, radicais e securitários, mas que vão ao encontro dos medos e das incertezas das comunidades, ávidas de percepção de segurança. Estes discursos, propala-

76 Anabela MIRANDA RODRIGUES, Política Criminal - Novos Desafios, Velhos Rumos, in: Direito Penal Económico e Europeu - Textos Doutrinários, III vol., IDPEE, Coimbra Editora, Coimbra, 2009, p. 160.

77 Cfr. Winfried HASSEMER, A Segurança Pública no Estado de Direito, AAFDL, 1995, pp. 269 e ss.

78 Cfr. Zygmunt BAUMAN. Modernidade Liquida, Zahar, Rio de Janeiro, 2001.

79 Cfr. José de FARIA COSTA, A Criminalidade em um Mundo Globalizado: ou Plaidoyer por um Direito Penal Não Securitário, in: Direito Penal Económico e Europeu - Textos Doutrinários, Vol. III, IDPEE, Coimbra Editora, Coimbra, p. 113.

80 Cfr. Mário FERREIRA MONTE. O Futuro tem Direito Penal? O Direito Penal tem futuro? Apontamento introdutório à obra de Paulo S. FERNANDES, Globalização, "Sociedade de Risco" e o Futuro do Direito Penal, Almedina, Coimbra, 2001; Luís GRACIA MARTIN, El horizonte del finalismo y el derecho penal del enemigo, Tirant Lo Blanch, Valencia, 2005, pp. 127-129; 
dos, em regra, pelos novos leviatãs do séc. XXI, recuperam o recurso a sistema de repressão e antecipação da tutela penal, como são os casos dos programas de "tolerância zero", de "lei e ordem" soluções securitárias de deterrence, funcionalizadas ao único objectivo de favorecer a segurança cognitiva dos seus eleitores através do asseguramento da integridade do sistema. Avançam-se, para o efeito, promessas de flexibilização de categorias dogmáticas do direito penal, desformalização de princípios, erosão de garantias materiais e processuais legitimadas por discursos de ódio, xenofobia e racismo contra um suposto inimigo comum: o criminoso. É aquilo que FERRAJOLI denomina de "terrorismo penal", ou seja, numa inversão de valores: terrorismo não é uma qualidade dos factos combatidos, mas sim a própria actuação repressiva do sistema, cuja estratégia já não é a actuação preventiva em relação aos factos, mas pura e simplesmente suprimir os possíveis autores ${ }^{82}$. FARIA COSTA ${ }^{83}$ denomina esta tendência de glorificação do Estado punitivo. Quer-se menos Estado social e menos Estado regulador e intervencionista, mas requer-se mais Estado punitivo. Novamente, como no absolutismo, a ordem pública, a percepção de segurança e a tranquilidade das populações são valores macrossociais que tendem a ocupar o lugar do bem jurídico como critério legitimador da intervenção penal. ${ }^{84}$ É a concretização do "império do medo" de BARBER ${ }^{85}$. Esta tendência tem-se demonstrado mesmo ao nível das instituições internacionais e do direito supra-estadual, onde se tem instalado um discurso intolerante ${ }^{86} \mathrm{e}$ «belicista», marcado por palavras de ordem como "luta", "combate", "tolerância zero". ${ }^{87}$ É assim que, fruto do desenvolvimento da sociedade de comunicação aberta e global ${ }^{88}$, faz actualmente curso uma política criminal populista baseada em percepções empíricas, segundo a qual, sem Estado

81 Cfr., a propósito, com muito interesse, André LAMAS LEITE, Nueva Penologia, Punitive Turn y Derecho Penal: Quo Vadimus? Por la Incertidumbre (Pos) Moderna, in: InDret - Revista para el analisis del Derecho, nr. 2, Barcelona, 2013.

82 Cfr. Luigi FERRAJOLI, Democracia y Garantismo, Trotta, Madrid, 2008, p. 237.

83 Cfr. José de FARIA COSTA, A Criminalidade em um Mundo Globalizado: ou Plaidoyer por um Direito Penal Não Securitário, in: Direito Penal Económico e Europeu - Textos Doutrinários, Vol. III, IDPEE, Coimbra Editora, Coimbra, p. 114.

84 Cfr. José DIÉZ RIPOLLÉS, El Nuevo Modelo Penal de la Seguridad Ciudadana, in: Revista Electrónica de Ciencia Penal y Criminología (RECPC) 06-03, 2004. Vide tb. José DÍEZ RIPOLLÉS, De la Sociedad del Riesgo a la Seguridad Ciudadana: Un Debato desenfocado, in: Revista Electrónica de Ciencia Penal y Criminología (RECPC), 07-01, 2005.

85 Cfr. Benjamin BARBER, Fear's Empire: War, Terrorism and Democracy, W. W. Worton, New York, 2003.

86 Sobre esta tendência actual para um endurecimento das políticas criminais vide Paulo MOTA PINTO. Nota sobre o 'imperativo da tolerância' e seus limites, in Estudos em Memória do Conselheiro Luís Nunes de Almeida, Coimbra Editora, Coimbra, 2007; Luis Nunes de ALMEIDA. Tolerância, Constituição e Direito Penal, in: Revista Portuguesa de Ciências Criminais, Coimbra Editora, Coimbra, 2013, ano 13, n. ${ }^{\circ} 2$.

87 Pedro CAEIRO, Cooperação Judiciária na União Europeia, in: Direito Penal Económico e Europeu: Textos Doutrinários, Vol. III, Coimbra Editora, Coimbra, 2009, p. 76 ; José de FARIA COSTA, A Criminalidade em um Mundo Globalizado: ou Plaidoyer por um Direito Penal Não Securitário, in: Direito Penal Económico e Europeu - Textos Doutrinários, Vol. III, IDPEE, Coimbra Editora, Coimbra, p. 118.

88 Cfr. Winfried HASSEMER, Op. Cit., p. 269 e ss. 
punitivo, triunfará a criminalidade ${ }^{89}$. O direito penal, tradicionalmente perspectivado como um «direito de liberdade» vê-se cada vez mais confrontado com uma demanda por um sentimento de segurança, principalmente em face da percepção da ameaça do terrorismo, o qual conseguiu "gerar a incerteza da segurança em qualquer lugar e em qualquer minuto e promover a paneonomia emergente da teoria do perigo terrorista." ${ }^{\circ 0}$ A atitude social face à intervenção penal altera-se: de um direito penal garantista, as sociedades passam a clamar por um direito penal funcionalista. Um funcionalismo sistémico: por um lado, repressivo, capaz de conter a onda de violência da propalada ameaça terrorista. Por outro, modernizado, tecnológico, orientado a um fim: combater a ameaça da criminalidade organizada91. Trata-se de um sistema autopoiético, que elege o seu próprio objecto, método e finalidades, instrumento da realização de políticas criminais de cunho belicista próprias de um Estado de segurança..$^{92}$ A doutrina do Estado de segurança propõe a substituição da lógica liberal do direito à liberdade e segurança contra o Estado, por uma outra que propugna o direito à liberdade e segurança através do Estado (e como tarefa fundamental deste), recuperando, no fundo, o ideário de HOBBES e de LOCKE. É ROBBERTS quem propugna a ideia de que o indivíduo tem, perante o Estado, o poder de reclamar a protecção e promoção de um direito fundamental à segurança. Foi todavia ISENSEE que melhor formulou a ideia do direito à segurança, concebendo-o a partir da dialéctica liberdade-segurança e exprimindo a ideia de a segurança mais não é do que a liberdade defendida. ${ }^{93}$

Ao nível processual, existe claro dissenso entre os defensores de um modelo diferenciado para combater a criminalidade organizada e os que não aceitam essa via. Na verdade, vão ganhando espaço teorias que propugnam um paradigma processual diferenciado para o combate à criminalidade organizada e ao terrorismo, tendo como base o entendimento de que as soluções legais "se devem adequar aos contextos de actuação do comportamento intoleravelmente desviado"94. Estas teorias, de que é exemplo a doutrina de SCHÜNEMANN e, de um modo mais extremo, o Patriot Act norte-americano, defendem uma flexibilização das garantias político-criminais, substantivas e processuais ${ }^{95}$, ou seja, uma revisão das regras que limitam a acção da investigação criminal na descoberta da verdade mate-

89 Cfr. José de FARIA COSTA, A Criminalidade em um Mundo Globalizado..., cit., p. 115.

90 Manuel M. GUEDES VALENTE, Op. cit., p. 81.

91 Cfr. Anabela MIRANDA RODRIGUES, Politica Criminal..., cit., p. 163.

92 Cfr. DENNINGER, Der Prävenstionsstaat, apud Maria Margarida SILVA PEREIRA, Direito Penal - Direito do Risco, Comparticipação Crimininosa, Tráfico de Influência, Quid Iuris, Lisboa, 2012, p. 19.

93 Cfr. Maria Margarida SILVA PEREIRA, Op. cit., p. 20.

94 Bernd SCHÜNEMANN, Consideraciones criticas sobre la situación espiritual de la ciencia juridico-penal alemana, in: Annuario de Derecho Penal y Ciencias Penales, n. ${ }^{4}$ 49, fasc. 1, Jan. - Abril, San Bernardo, Madrid, 1996, pp. 202 e ss.

95 Cfr. José de FARIA COSTA, O Fenómeno da Globalização e o Direito Penal Económico, in: Direito Penal Económico e Europeu - Textos Doutrinários, Vol. III, Coimbra Editora, Coimbra, 2009, p. 107. 
rial, com especial relevo para os meios de obtenção de prova ${ }^{96}$, com óbvio prejuízo para os valores do Estado de Direito. No caso do Patriot Act, oblitera-se por completo o estatuto de arguido, com todo o prejuízo para os mais elementares direitos fundamentais da pessoa ${ }^{97}$, o que GUEDES VALENTE apelida de "esquizofrenia belicista"98. No ordenamento penal português já se assiste, no âmbito da investigação, bem como na restante actividade policial, a uma desjudicialização (até mesmo desjudiciarização) e a uma policializaçãa $0^{99}$ dos actos que contendem com os direitos fundamentais das pessoas ${ }^{100}$, de que pode citar-se, como exemplos, o arts. $177 . .^{\circ}$ n. ${ }^{o s} 2$ c) e n. ${ }^{\circ} 3,252^{\circ}{ }^{\circ}$-A do Código de Processo Penal e a alínea a) do art. $29 .^{\circ}$ da Lei de Segurança Interna (Lei n. ${ }^{\circ}$ 53/2008 de 29 de Agosto).

Todo este discurso baseia-se na convicção de que o respeito pelos direitos fundamentais é incompatível com a perseguição da criminalidade organizada e encontra eco nas sociedades pós-modernas, nas quais a diminuição da intervenção do Estado social teve como efeito o reforço do clamor pela intervenção punitiva estatal ${ }^{101}$. Neste contexto, o apelo à intervenção socializadora do direito penal sobre o criminoso ou a invocação dos seus direitos fundamentais diz-se serem ideias anacrónicas. Começa a ganhar terreno um certo «pânico moral» conducente a um discurso eficientista de inocuização, um discurso legalista de justiça absoluta e obrigatória, repressiva e potencialmente desumanizante ${ }^{102}$, que guindam o "valor segurança"103 à axiologia suprema do sistema. Uma tal ordem de valores seria assegurada por uma actuação fortemente repressiva, marcada pela antecipação da tutela penal a meros estados de perigosidade, através da punição de actos preparatórios e da identificação de grupos de risco segundo um cálculo actuarial probabilístico (actuarial justice) ${ }^{104}$, fundado na religião, ascendência geográfica, ideologia política ou de outra ordem dos indivíduos. Programas político-criminais de sobrepenalização, como o Law and Order americano, e de

96 Cfr. Bernd SCHÜNEMANN, Consideraciones criticas..., cit., pp. 202 e ss.

97 Cfr. Luigi FERRAJOLI, Op. cit., pp. 237 e ss.; Manuel M. GUEDES VALENTE, Direito Penal do Inimigo..., cit., p. 93.

98 Cfr. Manuel M. GUEDES VALENTE, Op. cit., p. 140 e ss.

99 O termo é de Manuel M. GUEDES VALENTE (Direito Penal do Inimigo..., cit., pp. 89-90).

100 Cfr. Winfried HASSEMER, A Segurança Pública no Estado de Direito, AAFDL, 1995, pp. 90-120.

101 Cfr. Laura ZÚÑIGA RODRIGUEZ, Política Criminal, Colex, Madrid, 2001, p. 266. Sobre as consequências da globalização para a noção de Estado, vide: Peter J. ANDERSON, Política Global do Poder, Justiça e Morte, Piaget, Lisboa, 1998, pp. 103 e ss. José de FARIA COSTA, O Fenómeno da Globalização..., cit., p. 114.

102 Cfr. Anabela MIRANDA RODRIGUES, Política Criminal..., cit., p. 165.

103 Cfr. Idem, ibidem.

104 Cfr. André Lamas LEITE, Nova penologia, punitive turn e direito criminal: quo vadimus? pelos caminhos da incerteza (pós-)moderna, in: Direito Penal - Fundamentos Dogmáticos e Político-Criminais - Homenagem ao Prof. Peter Hünerfeld, Coimbra Editora, Coimbra, 2013, p. 395-476; Vide, ainda, Bernardo del ROSAL BLASCO, Hacia un Derecho Penal de la Postmodernidad?, in: Revista Electrónica de Ciencia Penal y Criminología, 2009, n. ${ }^{\circ} 11-08$, p. 8-35. 
hipercriminalização $0^{105}$, como os inspirados na doutrina da «tolerância zero», são demonstração disso mesmo.

Tal programa de actuação abre caminho ao justicialismo ${ }^{106}$, o qual deriva, invariavelmente, na condenação a todo o transe, numa manifestação daquilo que FARIA COSTA apelida de "soberba ética" do Estado punitivo, considerando que aqueles que praticam crimes são eticamente inferiores, colando-lhes esse estigma de tal modo que qualquer ressocialização se assemelha muito improvável ${ }^{107}$

HASSEMER $^{108}$, da Escola de Frankfurt, é muito crítico à expansão e mutação do direito penal, transformando-se num aparelho de repressão comportamental, através da flexibilização, ainda que controlada dos seus princípios reitores e da desformalização da sua dogmática, em ordem a combater os novos fenómenos da instabilidade social e jurídica da pós-modernidade. $\mathrm{O}$ autor considera que a «falência» do sistema penal não pode dado por adquirida e que discursos como o de JAKOBS não estão materialmente sustentados em reais necessidades trazidas pelas insuficiências do direito penal de cunho garantista, herdado do racionalismo humanista. GUEDES VALENTE ${ }^{109}$ aponta que um possível abandono do paradigma penal vigente só se legitimará numa prévia avaliação de todos os múltiplos factores que condicionam a eficácia do sistema penal, desde o acerto das estratégias político-criminais vertidas nas soluções legais, passando pela preparação dos agentes do sistema, até à própria responsabilidade do Estado no cumprimento dos seus programas sociais e económicos.

Se FERRAJOLI ${ }^{10}$ alerta para o facto de que a transformação da segurança colectiva no bem jurídico-penal por excelência pode conduzir à subversão da legalidade democrática, GUEDES VALENTE ${ }^{111}$ alerta para o perigo da sua substituição, a curto prazo, por um Estado de direito autoritário, capaz de proscrever a separação e interdependência de poderes por um autêntico estado-de-polícia. Quer isto dizer que, por exemplo, o enquadramento jurídico-penal do fenómeno do terrorismo, i.e., a tipificação da conduta numa dada facti

105 Fenómeno que se tem concretizado na tipificação penal de condutas outrora, e tradicionalmente, tratadas ao nível do ilícito de mera ordenação social e na expansão descontrolada do catálogo de crimes públicos, de que servem de exemplo os tipos penais previstos no Código das Sociedades Comerciais, nos arts. 509..$^{\circ}$ a $523 .^{\circ} \mathrm{e}$ $526 .^{\circ}$, com a agravante de que o regime premial previsto no art. $527 .^{\circ}$ para tais tipos é muito menos benéfico para o agente do que o previsto no Código Penal para os crimes contra o património em geral.

106 Sobre a actual tendência para o justicialismo penal, vide: Manuel M. GUEDES VALENTE, Direito Penal do Inimigo..., cit., p. 91 e ss.

107 Cfr. José de FARIA COSTA, A Criminalidade em um Mundo Globalizado: ou Plaidoyer por um Direito Penal Não Securitário, in: Direito Penal Económico e Europeu - Textos Doutrinários, Vol. III, IDPEE, Coimbra Editora, Coimbra, p. 121.

108 Cfr. Winfried HASSEMER, A Segurança Pública no Estado de Direito, AAFDL, 1995, pp. 91 e ss.

109 Cfr. M. Monteiro GUEDES VALENTE, Direito Penal do Inimigo..., cit., pp. 77 e ss.

110 Cfr. Luigi FERRAJOLI, Op. cit., p. 250.

111 Cfr. Manuel M. GUEDES VALENTE, Op. cit., pp. 77 e 78. 
species, não pode significar um tratamento dogmático e processual à margem dos preceitos constitucionais vigentes ao nível das garantias fundamentais do arguido ${ }^{112}$. Esse enquadramento há-de ser imbuído do humanismo garantista, por sua vez inspirado na axiologia consagrada na DUDH de 1948, filha da Bill of Rights de 1689 e das Declarações de 1776 e de 1789. Não podemos retroceder à lógica do direito penal do autor através da admissão de uma lógica de sistemas penais paralelos, em que coexistem, em vigência efectiva, direito penal do facto e direito penal do autor. Este último, de pendor niilista, tendente à reificação do agente através da sua despersonalização ${ }^{113}$, da admissão de um estatuto de não-pessoa de que nos fala GRACIA MARTÍN. ${ }^{114}$ Nas palavras de Anabela MIRANDA RODRIGUES: é "o retrocesso a um tempo em que o estranho, o desviante, é um delinquente inimigo e quem está fora do pacto social é alguém contra quem há que lutar."15

Para autores como FREITAS DO AMARAL ${ }^{116}$, a pós-modernidade coloca ao direito penal um desafio: não enveredar por estratégias de deterrence, antes achar um novo equilíbrio entre as necessidades de segurança e o imperativo do respeito pelos direitos fundamentais. Ora, estamos em crer que esse equilíbrio deve ter como referente fundamental a dignidade da pessoa humana ${ }^{117}$. Logo, qualquer estratégia de política criminal deve ter em conta que o Homem é, acima de tudo, um ser livre e que restringir a liberdade (valor da segurança) para garantir a liberdade é um raciocínio antitético quando se esquece a dignidade da pessoa.

Não obstante, na actualidade, "os [...] movimentos de sobrepenalização e de segurança convergem e reforçam-se para fazerem da norma penal e da justiça repressiva o derradeiro baluarte de uma sociedade com falta de referências."118

112 Manuel M. GUEDES VALENTE (Direito Penal do Inimigo..., cit., p. 84) aponta, em particular, os arts. $1 .^{\circ}, 2 .^{\circ}, 9 .^{\circ}$, $18 .^{\circ}, 29 .^{\circ}$ e $32 .^{\circ}$ da CRP.

113 Cfr. Luigi FERRAJOLI, Democracia y Garantismo, Trotta, Madrid, 2008, p. 237.

114 Cfr. Luis GRACIA MARTÍN, O Horizonte do Finalismo..., cit., p. 132.

115 Anabela MIRANDA RODRIGUES, Política Criminal..., cit., p. 162, Vide, a propósito da recuperação da ideia de «inimigo», Laura ZUÑIGA RODRIGUEZ. Redes Internacionales y Criminalidad: a Propósito del Modelo de Participación en Organización Criminal, in: El Derecho Penal Ante La Globalización, Laura ZUÑIGA RODRIGUEZ; Cristina MENDEZ RODRIGUEZ, M. Rosario DÍAZ-SANTOS (coords.), Colex, Madrid, 2002.

116 Cfr. Diogo FREITAS DO AMARAL, Do 11 de Setembro à Crise do Iraque, Bertrand, Lisboa, 2003, p. 53.

117 Cfr. Chäim PERELMAN. Ética e Direito, Piaget, Lisboa, 2002, p. 360 . Escreve o autor: “(..) a pessoa humana possui uma dignidade que lhe é própria e ela merece o respeito enquanto sujeito moral livre, autónomo e responsável. (...) Com efeito, se é o respeito pela dignidade humana que é a condição de uma concepção jurídica de direitos humanos, (...) é preciso admitir como corolário a existência de um sistema de direito com o poder de coagir. (...) $\mathrm{Na}$ falta de impor esse respeito ao próprio poder, este, sob pretexto de proteger os direitos do Homem, corre o risco de se tornar tirânico e arbitrário. Para evitar essa arbitrariedade é, pois, indispensável limitar os poderes de toda a autoridade encarregue de proteger o respeito pela dignidade das pessoas, o que supõe um Estado de Direito e a independência do poder judicial." Chäim PERELMAN, ibidem.

118 François OST, O Tempo do Direito, Piaget, Lisboa, 2001, p. 383. 


\section{Um direito penal para a «sociedade do risco» pós-moderna: ainda o carácter ins- trumental do direito penal?}

A falência e consequente superação da razão técnico-instrumental calculadora na sociedade pós-industrial, conjugada com o emergir de uma «sociedade do risco» coloca o direito penal perante um dilema: persistir na matriz liberal do direito penal mínimo e instrumental ou abandonar o paradigma e substituí-lo por uma nova dogmática jurídico-penal, fundamentada numa política criminal marcada pelo abandono do axioma da finalidade exclusiva de protecção de bens jurídicos em favor de um direito penal de imposição de puras normas de comportamento ${ }^{119}$. O direito penal perderia o seu carácter mínimo e, a coberto de novos programas constitucionais, tornar-se-ia um direito de prima (ou sola) ratio, ou seja, um instrumento de governo social. ${ }^{120} \mathrm{O}$ paradigma penal para a «sociedade do risco» há-de achar-se, pois, algures entre a manutenção dos «monólitos juridicamente corporizados» de que falava RUPP ${ }^{121}$ e a superação total do carácter instrumental do direito penal, funcionalizando-o por completo a uma política criminal de puro controlo e gestão de riscos numa perspectiva de prevenção geral integradora, na qual a efectividade da liberdade é condicionado pelas reais condições de exercício desse direito, o que subordina um direito fundamental às decisões do Estado em termos de oportunidade, nomeadamente em sede de legislação ordinária. ${ }^{122}$

Conceber-se-ia, desta forma, um direito penal perfeitamente autopoiético, à boa maneira do proposto por HONIG ${ }^{123}$ e ferozmente criticado por MOCCIA ${ }^{124}$.

SILVA DIAS ${ }^{125}$ dá-nos conta de que "as preocupações de segurança desencadearam uma «fuga para o direito penal» que é responsável pelas tendências de sobre-criminalização (...), antecipação da tutela penal, etc." SCHULZ ${ }^{126}$ aponta que aumento da sensação (percepção) de insegurança e uma maior sensibilidade aos riscos potenciados por uma sociedade em contínua e cada vez mais rápida mutação, provocarão uma inexorável expansão das incriminações. O problema que hoje se coloca é, precisamente, o de saber se essa expansão do

119 Cfr. Günter JAKOBS; Manuel CANCIO MELIÁ, Derecho Penal del Enemigo, Cuadernos Civitas, Madrid, $2003, \mathrm{p}$. 60 e ss.

120 Jorge de FIGUEIREDO DIAS, O direito penal entre a "sociedade industrial" e a "sociedade do risco", in: Estudos em Homenagem ao Prof. Doutor Rogério Soares, BFDUC, Stvdia Ivridica, n. ${ }^{\circ} 61$, Outubro de 2001, p. 597.

121 Cfr. Jorge de FIGUEIREDO DIAS, Op. cit., p. 588.

122 Cfr. Maria Margarida SILVA PEREIRA, Op. Cit., p. 23.

123 Cfr. Manuel da COSTA ANDRADE, Consentimento e Acordo em Direito Penal, Coimbra Editora, Coimbra, 1991, pp. 42 e ss.

124 Cfr. Sérgio MOCCIA. De la tutela de bienes a la tutela de funciones: entre ilusiones postmodernas y reflujos iliberales, in: Política Criminal y Nuevo Derecho Penal (libro homenaje a Claus Roxin), Bosch, Barcelona, 1997.

125 Augusto SILVA DIAS, Protecção Jurídico-Penal do Interesses dos Consumidores, $3 .^{\text {a }}$ ed. policop., FDUC - IDPEE, Coimbra, 2001, p. 5, p. 21. Cfr. Hermínio RODRIGUES, op. cit., p. 22.

126 Lorenz SCHULZ, De la aceleración de las condiciones de vida, in: La Insostenible Situación del Derecho Penal, Comares, Granada, 1999, pp. 447-468. 
direito penal corresponderá à identificação de novos bens jurídicos ou se o direito penal da «sociedade do risco» se transformará num direito totalmente funcionalizado ao controlo dos novos e grandes riscos. O que vale por questionar se o direito penal, tal como o conhecemos, cabe algum papel na defesa das gerações futuras, ou se terá de se tornar em um «direito penal do risco».

ROXIN $^{127}$ assinala que, ao combater os novos riscos através da intervenção do direito penal, há que preservar a subordinação dessa intervenção ao princípio da protecção do bem jurídico e aos demais princípios de imputação jurídico-penal próprios de um Estado de Direito. Onde tal desígnio não seja possível, o direito penal deve abster-se de intervir. É justamente aqui que as divergências doutrinais começam, dividindo-se a doutrina em três facções: uma, mais conservadora, nega a intervenção do direito penal nos domínios do risco. Outra, assumindo uma posição de ruptura paradigmática, propõe a completa funcionalização do direito penal aos valores da segurança colectiva e da paz social. Numa posição intermédia, está a doutrina que propõe um expansionismo controlado do direito penal através da sua estruturação em diferentes níveis de actuação.

A doutrina da Escola de Frankfurt, representada por autores como HASSEMER, HERZOG e PRITTWITZ, nega que o direito penal possa e deva ser o instrumento ao qual os Estados hão-de recorrer para mitigar os problemas do risco, pois antevê que a intervenção do direito penal nessa matéria fará com que este se adultere, funcionalizando-se e desformalizando-se paulatinamente por influência de políticas criminais securitárias, às quais os Estados serão inevitavelmente conduzidos, perante a ubiquidade e incontrolabilidade dos novos riscos e a necessidade de incutir a sensação de segurança na comunidade ${ }^{128}$. A funcionalização do direito penal manifestar-se-ia, essencialmente, pela sua expansão e administrativização em detrimento de princípios como o da protecção exclusiva de bens jurídicos, o princípio da subsidiariedade, o princípio da mínima intervenção, aproximando-se da ideia de um direito de mera ordenação social, marcado pela excessiva antecipação da tutela penal, através da eleição de bens jurídicos vagos, ou mesmo através da proliferação de crimes de perigo abstracto e crimes de perigo comum, e na enfatização da prevenção geral positiva ou inte-

127 Claus ROXIN, Derecho Penal. Parte General. Tomo I. Fundamentos. La estructura de la Teoría del Delito, Traducción de LUZÓN-PEÑA; García CONLLEDO; Vicente REMESAL, Civitas, Madrid, 1997, p. 61. Cfr. Hermínio RODRIGUES, op. cit. P. 24. Vide, tb., Francisco MUÑOZ CONDE. Protección de Bienes Jurídicos como Limite Constitucional al Derecho Penal, Quintero Olivares / Morales Prats (Coords.). El Nuevo Derecho Penal Español Estudios Penales en Memoria del Profesor José Manuel Valle Muñiz, Editorial Aranzadi, Madrid, 2001.

128 Cfr. Winfried HASSEMER, Perspectivas del Derecho Penal Futuro, Revista Penal, Universidad de Huelva, 1998, p. 37-41; Winfried HASSEMER, Crisis y características del moderno derecho penal. Actualidad Penal, n. ${ }^{\circ}$ 43/22, Madrid, 1993, p. 635-646. 
gradora como fim da pena ${ }^{129}$. A desformalização revelar-se-ia, quer no recurso a técnicas legislativas obscuras, caracterizadas pelo uso corrente de conceitos indeterminados, cláusulas gerais e normas penais total ou parcialmente em branco, quer na flexibilização das categorias dogmáticas tradicionais, como a culpa, objectivando a responsabilidade penal e proscrevendo o próprio princípio da legalidade $\mathrm{e}^{130}$. Os penalistas da Escola de Frankfurt apenas admitem a intervenção do direito penal nos moldes de uma construção jurídico-penal de matriz estritamente liberal, caracterizada pela protecção de bens jurídicos individualizáveis (concepção monista-pessoal) e pela manutenção da função crítica ${ }^{131}$ do conceito de bem jurídico, sendo, que, nesses moldes, será totalmente ineficaz para a promoção da segurança das gerações futuras sem que se transforme num direito penal parcial. ${ }^{132}$ Pelo que, para assegurar a protecção perante os «mega-riscos» há que lançar mão de outros ramos do Direito e, sobretudo, de meios não jurídicos de controlo social ${ }^{133}$, mais orientados em termos preventivos, renunciando à reprovação pessoal e à imposição de penas privativas da liberdade ${ }^{134}$. A este sistema paralelo ao direito penal chamou HASSEMER de "direito de intervenção", o qual, na verdade, é algo muito próximo de uma tutela administrativa reforçada ${ }^{135}$.

Precisamente nos antípodas das teses da Escola de Frankfurt, encontram-se aqueles que defendem a mudança de perspectiva do direito penal para uma lógica inteiramente funcionalizada às exigências próprias da «sociedade do risco»: uma lógica de controlo social marcado pela atenuação grave de princípios básicos de raiz iluminista e liberal, pela recusa

129 Peter Alexis ALBRECHT, El Derecho Penal en la intervención de la política populista, in: La Insostenible Situación del Derecho Penal, Comares, Granada, 2000, pp. 474-475. Cfr. Hermínio RODRIGUES, op. cit., p. 25.

$130 \mathrm{Cfr}$. Wolfgang NAUCKE, La progressiva pérdida de contenido del princípio de legalidade penal como consecuencia de um positivismo relativista y politizado, in: La Insostenible Situación del Derecho Penal, Comares, Granada, 1993, pp. 531 e ss.

131 Winfried HASSEMER, Persona, mundo y responsabilidad. Bases para una teoria de la imputación en Derecho Penal, Tirant lo Blanch, Valencia, 1999, p. 40.

132 Cornelius PRITTWITZ, O Direito Penal entre o Direito Penal do Risco e o Direito Penal do Inimigo: Tendências Actuais em Direito Penal e Politica Criminal, in: Revista Brasileira de Ciências Criminais, São Paulo, Revista dos Tribunais - n. ${ }^{\circ} 47$, IBCCRIM, Mar/Abr. 2004.

133 Cfr. Winfried HASSEMER, Persona, mundo y responsabilidad. Bases para una teoria de la imputación en Derecho Penal, Tirant lo Blanch, Valencia, 1999, pp. 67-73.; Felix HERZOG, Limites del Derecho Penal para controlar los riesgos sociales, in: Poder Judicial n. ${ }^{\circ}$ 32, 1993, pp. 80 e ss. Contra, Jorge de FIGUEIREDO DIAS, Direito Penal, Parte Geral - Tomo I..., cit., Coimbra Editora, Coimbra, 2004, p. 131 e ss. e Jorge de FIGUEIREDO DIAS, O direito penal entre a "sociedade industrial" e a "sociedade do risco", BFDUC, Stvdia Ivridica, n. ${ }^{\circ} 61$, Coimbra, 2001, p. 596.; Claus ROXIN, Derecho Penal - Parte General..., cit., pp. 61-62; MARINUCCI / DOLCINNI, Diritto penale minimo e nuove forme de criminalitá, Rivista Italiana di Diritto e procedura penale, 1999, pp. 808 e ss. Cfr., também, Augusto SILVA DIAS, Op. cit., p. 28. Cfr. Hermínio RODRIGUES, op. cit., p. 28.

134 Cfr. Winfried HASSEMER; Francisco MUÑOZ CONDE, La Responsabilidad por el Producto en Derecho Penal, Tirant lo Blanch, Valencia, 1995, p. 46 e Winfried HASSEMER, Person, Welt und Werantwortlichkeit. Prolegomena einer Lehere von der Zurechnung im Strafrecht", apud Mário Ferreira MONTE, O Direito Penal tem futuro..., apontamento introdutório a Paulo S. FERNANDES, Globalização, Sociedade do Risco e o Futuro do Direito Penal, Almedina, Coimbra, 2001, p. 25. Cfr. Hermínio RODRIGUES, op. cit., p. 28.

135 Cfr. Jorge de FIGUEIREDO DIAS, Op. cit., pp. 131; Vide, tb., Jorge de FIGUEIREDO DIAS, O direito penal entre a "sociedade industrial" e a "sociedade do risco"..., cit., p. 596. 
total do reconhecimento da ordem axiológica que advém do axioma onto-antropológico do direito penal e pela eleição da gestão do risco, através da neutralização e inocuização de certos grupos, como fim último da ordem punitiva. ${ }^{136}$ É uma proposta baseada na aplicação do dogma da razão técnico-instrumental na prevenção dos novos (e dos velhos) riscos, levando-o ainda mais longe sob a forma de uma razão calculadora probabilística. ${ }^{137}$ No direito anglo-saxónico, fala-se mesmo de uma "actuarial justice"138, ou seja, no uso do cálculo de probabilidades na prevenção criminal, o que passa pela identificação de certos grupos de alto potencial criminógeno. As teorias criminológicas interaccionistas da sociologia criminal norte-americana ganham aqui expressão, já que a doutrina da justiça actuarial parte do pressuposto de que o crime é um factor social conatural que deve ser gerido por referência a índices, sendo a reacção do sistema orientada para a gestão de perfis de risco numa actuação profiláctica de pura prospecção, no sentido do evitamento e não da prevenção propriamente dita. Mais do que penas, este sistema propõe autênticas medidas de segurança baseadas numa perigosidade probabilística aferida por indicadores estatísticos ${ }^{139}$. Assim se lograria uma redução dos danos globais inerentes ao crime, através de uma adequada redistribuição dos riscos, tanto no plano da prevenção como no plano da repressão ${ }^{140}$.

Concepção muito próxima é preconizada por JAKOBS. Apontando a incapacidade do direito penal tradicional e da dogmática penal finalista para responder de forma eficaz ao sentimento generalizado de insegurança no universo da globalização, JAKOBS preconiza o advento de uma nova lógica sancionatória de pendor fortemente funcionalista. Em total oposição com uma política criminal fundada na tutela de direitos fundamentais dos cidadãos, despreza o critério da protecção do bem jurídico e elege a tutela da validade da norma como propósito fundamental. ${ }^{141}$

Idealizando um sistema dualista, baseado nas teorias de KANT e de HOBBES, distinguindo entre «cidadão» e «inimigo», entre «pessoa» e «objecto», bem como nas concepções de ROUSSEAU e FICHTE sobre a quebra do contrato social e, ainda, da violação do con-

136 Cfr. Hermínio RODRIGUES, op. cit., p. 35.

137 Idem, ibidem.

138 Cfr. André Lamas LEITE, Nova penologia, punitive turn e direito criminal: quo vadimus? pelos caminhos da incerteza (pós-)moderna, in: Direito Penal - Fundamentos Dogmáticos e Político-Criminais - Homenagem ao Prof. Peter Hünerfeld, Coimbra, Coimbra Editora, 2013, p. 395-476; Bernardo del ROSAL BLASCO, Hacia un Derecho Penal de la Postmodernidad?, in: Revista Electrónica de Ciencia Penal y Criminología, 2009, n. ${ }^{\circ}$ 11-08, p. 8-35; M. FREELEY / J. SIMON, Actuarial Justice: The Emerging New Criminal Law, in: Crime and the Risk Society, O'MALLEY (org.) 1998, p. 375. Vide, tb. Bernardo del ROSAL BLASCO, Hacia un Derecho Penal de la Postmodernidad?, in: Revista Electrónica de Ciencia Penal y Criminología, 2009, n. ${ }^{0}$ 11-08, p. 8-35 e Pedro CAEIRO, Legalidade e oportunidade: a perseguição penal entre o mito da "justiça absoluta" e o fetiche da "gestão eficiente" do sistema, RMP 84, 2000, p. 31 e ss.

139 Cfr. Hermínio RODRIGUES, op. cit., p. 37.

140 Pedro CAEIRO, Legalidade e oportunidade: a perseguição penal entre o mito da "justiça absoluta" e o fetiche da "gestão eficiente" do sistema, in: RMP 84, 2000, p. 44.

141 Cfr. Hermínio RODRIGUES, op. cit., pp. 29-33. 
senso de LEIBNIZ, JAKOBS propõe a aplicação de um direito penal nos moldes tradicionais para aqueles que são normalmente cumpridores (cidadãos) e um outro para aqueles que sejam habitual e reiteradamente delinquentes (inimigos). Para estes, aposta num sistema axiologicamente neutro onde o valor supremo é a integridade da norma, na melhor tradição de HEGEL. A esse sistema chamou: "direito penal do inimigo". Segundo JAKOBS ${ }^{142}$, o direito penal do inimigo caracteriza-se, essencialmente, por três elementos, sendo o primeiro deles a antecipação da tutela penal, ou seja, trata-se de um direito penal cujo referente essencial é o perigo (risco mesmo!) do cometimento do delito, a iminência real ou conjectural do crime, e não o facto criminoso, tratando-se, assim, de um direito penal que não se funda no facto cometido mas na probabilidade de (ou propensão para) o cometer. Assim, a natureza intrínseca do conceito de "direito penal do inimigo" está em ser uma reacção violenta do ordenamento jurídico contra indivíduos especialmente perigosos, aplicando medidas de segurança de modo a conter ao máximo o espaço de livre actuação desses indivíduos, apostando tudo na neutralização do «inimigo» da paz social. A finalidade do direito penal passa a ser a tutela da norma e do sistema. O bem jurídico poderá ser indirectamente protegido, mas já não terá qual função crítica, dogmática ou legitimadora ${ }^{143}$.

Numa posição intermédia entre a preservação do carácter puramente instrumental do direito penal e a sua completa funcionalização está a doutrina que defende um expansionismo moderado, a qual encontra melhor exemplo na teoria do direito penal «a duas velocidades» de SILVA-SANCHÉZ. Partindo, tal como HASSEMER, da convicção de que a configuração e as aspirações das novas sociedades exigem uma expansão do direito penal e que este não poderá, por muito mais tempo, conservar as mesmas exigências dogmáticas ${ }^{144}$, SILVA-SANCHÉZ procura responder ao problema através de uma política de expansão do

142 Cfr. Günther JAKOBS; Manuel CANCIO MELIÁ, Derecho penal del inimigo, Civitas, Madrid, 2003, p. 30 e ss. Cfr. tb., Günther JAKOBS, La Ciencia Penal ante los Retos del Futuro, in: Albin ESER / Winfried HASSEMER / Björn BURKHARDT, La ciencia del Derecho Penal ante el cambio de Milenio, Trad. de Teresa MANZO, Francisco MUÑOZ CONDE (Coord.), Valencia, 2004; F. MUÑOZ CONDE El nuevo Derecho penal autoritario, in: El Derecho ante la globalización y el terrorismo, AA. VV., Tirant lo Blanch, Valencia, 2004; F MUÑOZ CONDE, El nuevo Derecho penal autoritario: consideraciones sobre el llamado Derecho penal del enemigo, in: Mutaciones de Leviatán. Legitimación de los nuevos modelos penales, AA. VV., Akal, Madrid, 2005: Miguel POLAINO-ORTS, Derecho Penal del Enemigo. Fundamentos, Potencial de Sentido y Limites de Vigencia, Bosch, Barcelona, 2009; Luis GRACIA MARTIN, El horizonte del finalismo y el derecho penal del enemigo, Tirant Lo Blanch, Valencia, 2005; Luis GRACIA MARTIN, Consideraciones Criticas Sobre al Actualmente Denominado Derecho Penal del Enemigo, in: Revista Electrónica de Ciencia Penal y Criminología (RECPC) 07-02, 2005. Cfr. Hermínio RODRIGUES, op. cit., p. 32.

143 Günther JAKOBS, Sobre la Normativización de la Dogmática Jurídico-Penal, trad. CANCIO MELIÁ / FEIJÓO SANCHÉZ, Thomson-Civitas, Madrid, 2003, pp. 59-61. Cfr. Hermínio RODRIGUES, op. cit., p. 30.

144 Jesús María SILVA-SANCHÉZ (La Expansión del Derecho Penal..., cit., pp. 65 e ss.) diz: "La visión del Derecho penal como único instrumento eficaz de pedagogía político-social, como mecanismo de socialización, de civilización supone una expansión ad absurdum de la otrora ultima ratio." 
direito penal consubstanciada numa dogmática dualista, que resulta naquilo que chama de "direito penal de (ou a) duas velocidades"145.

Defendendo, como TIEDEMANN ${ }^{146}$, uma divisão do direito penal em sectores de intervenção, consoante os tipos de criminalidade, SILVA-SANCHÉZ propõe uma estruturação em dois níveis que correspondem a outras tantas lógicas de intervenção. Deve, segundo o autor, manter-se a existência de um cerne de direito penal, relativamente ao qual valham, imodificados, os princípios do direito penal clássico, dirigido à protecção subsidiária e fragmentária de bens jurídicos individuais. Mas, considera o autor, deve existir também uma periferia jurídico-penal, especificamente dirigida à protecção contra os "grandes e novos riscos", onde aqueles princípios se encontrem esbatidos ou mesmo transformados. Para tanto, propõe um modelo de "flexibilização controlada"147 das regras de imputação (responsabilidade das pessoas colectivas, ampliação dos critérios da autoria e da comissão por omissão, etc.) e dos princípios de garantia do direito penal clássico como forma de responder à necessidade de protecção das sociedades actuais.

Onde a proposta de SILVA-SÁNCHEZ é inovadora face ao direito de intervenção de HASSEMER é no facto de que a «flexibilização controlada» que propõe ter lugar dentro do direito penal e não numa lógica de administrativização do combate aos novos riscos. Ou seja, SILVA-SANCHÉZ não nega aptidão do direito penal para resolver os problemas da sociedade pós-moderna, pós-industrial e globalizada. Simplesmente considera que não o poderá fazer mantendo o seu carácter garantista nos moldes tradicionais, havendo de se expandir a novas formas de actuação, mais adaptadas ao contexto da sociedade do risco. Contudo, não quer isto dizer que o direito penal haja de perder de vista a sua função protectora de bens jurídicos, designadamente os bens jurídicos supra-individuais.

Da análise destas três grandes tendências resulta patente que a eventual mudança de paradigma na concepção de um direito penal para a «sociedade do risco» depende, em muito, da viabilidade da manutenção do bem jurídico-penal como referente fundamental da política criminal, ou seja, a sua preservação como topos do direito penal pós-moderno. $\mathrm{O}$ direito penal do futuro visará a protecção exclusiva e subsidiária de bens jurídicos contra a sua lesão ou perigo de lesão ou o puro controlo de risco?

Para quem preconize uma concepção puramente monista-pessoal dos bens jurídicos penais, como os autores da escola de Frankfurt, não cabe ao direito penal qualquer papel na

145 Jesús Maria SILVA-SANCHÉZ, La Expansión del Derecho Penal..., cit., pp. 121 e ss. Cfr. Hermínio RODRIGUES, op. cit.. p. 38.

146 Cfr. Augusto SILVA DIAS, Protecção Jurídico-Penal do Interesses dos Consumidores, 3 a $^{\text {a }}$ ed. policop., FDUC - IDPEE, Coimbra, 2001, p. 36.

147 Jesús Maria SILVA-SÁNCHEZ, Op. cit., p. 125, nota 85. Cfr. Hermínio RODRIGUES, op. cit., p. 38. 
resposta aos problemas macro-sociais da sociedade futura, pelo que não está em causa, de modo algum, o abandono do seu carácter instrumental. As respostas adequadas residem em sistemas não-penais de controlo, sendo que a linha de fronteira para a intervenção do direito penal consiste, precisamente, no bem jurídico individual ${ }^{148}$.

Partidários do expansionismo controlado, como SILVA DIAS e SILVA-SÁNCHEZ, defendem, numa concepção dualista do objecto do direito penal, que o direito penal só logrará um papel adequado na contenção dos mega-riscos na medida em que se adapte à protecção, a par de bens jurídicos individuais, de bens jurídicos supra-individuais ou intermédios, desde que estes tenham um referente pessoal ${ }^{149}$, isto é, que protejam um interesse ou valor individualmente fruível, o que sucede desde que o respectivo dano afecte pessoas ou interesses pessoais.

Já autores como ROXIN e SCHÜNEMANN ${ }^{150}$, concebem estes bens jurídicos supra-individuais como sendo instrumentos para a protecção de interesses individualmente fruíveis. Para esta teoria, há bens jurídicos que, atento o seu carácter essencial para a preservação das condições necessárias à sobrevivência da própria humanidade, assumiriam relevância penal instrumental, sendo a sua protecção uma técnica de antecipação da tutela dos "valores-fins" essenciais, protegidos pelos bens jurídicos individuais. ${ }^{151}$ Para esta teoria,

148 Cfr. Winfried HASSEMER, Persona, mundo y responsabilidad. Bases para una teoría de la imputación en Derecho Penal, trad. de F. Muñoz Conde y M.M. Díaz Pita, Tirant lo Blanch, Valencia, 1999, pp. 30-38; Winfried HASSEMER, Perspectivas del Derecho Penal del Futuro, RP, n. ${ }^{\circ} 1$ (1997), pp. 37 e ss.; winfried HASSEMER, Contra el abolicionismo: acerca del porqué no se deberia suprimir el derecho penal, RP, n. ${ }^{\circ} 11$ (2003), pp. 31 e ss.; Winfried HASSEMER, Lineamentos de una teoría personal del bien jurídico, DP, Año 12(1989), p. 275 e ss.; Na mesma linha seguem Luigi FERRAJOLI, Diritto e Ragione. Teoria del Garantismo Penale, Laterza, Roma, 1990, p. 479-481; LÜDERSSEN, apud Cornelius PRITTWITZ, El Derecho Penal Alemán: ¿fragmentario? ¿subsidiario? ¿ultima ratio? Reflexiones sobre la razón y limites de los principios limitadores del Derecho penal", in: La insostenible situación del Derecho penal, AA. VV., trad. Maria Teresa Castiñeira Palou, Granada, Comares, 2000, p. 433.

149 Cfr. Augusto SILVA DIAS, Op. cit., p. 29; Augusto SILVA DIAS, Entre «comes e bebes»: debate de algumas questões polémicas no âmbito da protecção jurídico-penal do consumidor, IDPEE, vol. III, Coimbra Editora, Coimbra, 2009, p. 485; Jesús Maria SILVA-SÁNCHEZ, La Expansión del Derecho Penal. Aspectos de la Politica Criminal en las Sociedades Postindustriales, Civitas, Madrid, 1999, p. 98. No mesmo sentido, vide Ricardo M. MATA Y MARTíN, Bienes jurídicos intermedios y delitos de peligro : aproximación a los presupuestos de la técnica de peligro para los delitos que protegen bienes jurídicos intermedios, Granada : Comares, 1997, p. 23 e ss.; José de FARIA COSTA, Direito Penal Económico, Quarteto, Coimbra, 2003, p. 35 e ss.; Mirentxu CORCOY BISADOLO (Delictos de Peligro y Protección de Bienes Jurídico-penales Supraindividuales, Valencia, Tirant lo Blanch, 1999, pp. 139 e ss.; Sergio MOCCIA, De la tutela de bienes a la tutela de funciones: entre ilusiones postmodernas y reflujos iliberales, in: Política Criminal y Nuevo Derecho Penal (libro homenaje a Claus Roxin), Bosch, Barcelona, 1997, pp. 118-119 e ss.

150 Claus ROXIN, Derecho Penal, trad. Luzón Peña, Garcia Conledo, Vicente Remesal, Civitas, Madrid, reimp. 2000, pp. 410-411. Entre nós, vide Augusto SILVA DIAS, Delicta in se e delicta mere prohibita: uma análise das descontinuidades do ilícito penal moderno à luz da reconstrução de uma distinção clássica, FDUL Lisboa, 2003, pp. 820 e ss.

151 Cfr. Fernando MANTOVANI, Diritto Penale, Pádova, CEDAM, 2001, p. 208. Vide, tb. Fernando MANTOVANI, Principio di ofensivitá tra dogmatica e politica criminale, in: Il Diritto Penale alla Svolta di Fine Millenio, G. Giappichelli Editore, Torino, 1998, p. 248 e ss.; Carlos MÁRTINEZ-BUJAN PEREZ, Derecho Penal Económico - Parte General, Tirant lo Blanch, Valencia, 1998, pp. 93-96. Em sentido contrário, vide Augusto SILVA DIAS, Delicta in se..., cit., p. 690, para quem os bens jurídicos supra-individuais não se encontram em tal relação de subornação e de instrumentalidade. 
portanto, um direito penal para a «sociedade do risco» deveria assumir, como sua função primordial, o asseguramento das condições essenciais, de uma perspectiva macro-social, para que os bens jurídicos individuais possam ser fruídos. Essa função seria prosseguida, justamente, pela redução do grau de risco de lesão destes bens jurídicos individuais, o que passaria por uma intensificação da tutela preventiva em relação à lesão dos bens jurídicos instrumentais. ${ }^{152}$

Uma parte da doutrina vai ainda mais longe e avança o conceito de bem jurídico colectivo na própria acepção do termo. É o que defendem autores como FIGUEIREDO DIAS ${ }^{153}$, TIEDMANN ${ }^{154}$, HEFENDEHL ${ }^{155}$. A necessidade de reconhecer os bens jurídicos colectivos como valores e interesses dignos de protecção penal, ao lado dos bens jurídicos estritamente individuais, decorre, inexoravelmente, dos problemas com que o direito penal se depara na protecção dos pilares axiológicos que sustentam as sociedades pós-modernas. Para FIGUEIREDO DIAS, a especificidade do bem jurídico colectivo reside no facto de poder ser gozado por todos e por cada um, sem que ninguém deva ficar excluído; nessa possibilidade de gozo reside o legítimo interesse individual na integridade do bem jurídico colectivo $^{156}$. O autor rejeita, pois, uma concepção de bem jurídico demasiado antropocêntrica "que de bem jurídico só permite falar quando estejam em causa interesses reais, tangíveis e, por consequência, também actuais do indivíduo"157, ou mesmo uma concepção moderada de bem jurídico colectivo que só lhe atribua relevância penal na medida em que o mesmo possa ser ligado a um interesse individual.

Reconhece-se, então, ao lado dos bens jurídicos individuais, a existência de verdadeiros bens jurídicos colectivos, bens jurídicos de carácter social, trans-individuais, sendo na respectiva tutela que reside o verdadeiro papel fundamental do direito penal do futuro.

STRATENWERTH, por outro lado, propõe a completa superação do conceito de bem jurídico e a sua substituição pela tutela directa de relações da vida como tais. Face aos novos desafios que se colocam ao direito penal pós-moderno, este autor prevê a falência do bem jurídico como referente fundacional da dignidade penal da conduta e justificação primeira

152 Cfr. Hermínio RODRIGUES, op. cit., p. 53.

153 Cfr. Jorge de FIGUEIREDO DIAS, O Papel do Direito Penal..., cit., p. 1129.

154 Cfr. Klaus TIEDEMANN, Lecciones de Derecho Penal Económico, PPU, Barcelona, 1993, p. 35. Vide, tb. LÓPEZ CALERA, Hay derechos colectivos? Individualidad y socialidade en la teoria de los derechos colectivos, Barcelona, Ariel, 2000.

155 Cfr. Roland HEFENDEHL, Debe Ocuparse El Derecho Penal de Riesgos Futuros? Bienes Jurídicos Colectivos y Delictos de Peligro Abstracto, in: Anales de Derecho, n. ${ }^{\circ}$ 19, Universidad de Murcia, 2001, p. 156.

156 Cfr. Susana AIRES DE SOUSA, Os Crimes Fiscais..., cit., p. 219. Cfr. Hermínio RODRIGUES, op. cit., p. 49.

157 Cfr. Jorge de FIGUEIREDO DIAS, O Papel do Direito Penal..., cit., p. 1130. Também Mário FERREIRA MONTE partilha desta visão. Cfr. Mário FERREIRA MONTE Da Protecção Penal do Consumidor. O problema da (des) criminalização do incitamento ao consumo, Coimbra, Almedina, 1996, pp. 206-207. Vide, ainda, J. J. Gomes CANOTILHO, Tomemos a Sério os Direitos Económicos, Sociais e Culturais, BFD, Coimbra, Coimbra Editora, 1988, p. 40. 
da intervenção penal ${ }^{158}$. Partindo da ideia de que, perante a complexidade e constante modificação das condutas lesivas dos interesses colectivos e uma cada vez maior indeterminabilidade do conceito de bem jurídico individual, pela erosão do seu referente pessoal, uma protecção penal de interesses colectivos eficaz exige que o ilícito material respectivo tenha de ser ancorado em condutas socialmente irrelevantes ou insignificativas na sua singularidade, só se tornando socialmente danosas em associação com condutas análogas ocorridas em massa ${ }^{159}$. Assim, em substituição do desvalor do resultado aferido no dano ou no perigo de lesão do bem jurídico, STRATENWERTH avança o conceito de ultrapassagem do valor-limite como critério de intervenção penal. Trata-se de opor exigências de valor intensificadas aos que participam de actividades geradoras de grandes riscos, «grandes normas de comportamento ${ }^{160}$. O cumprimento destes deveres permitiria a diminuição dos limites do risco permitido e na formulação de novas posições de garante, nomeadamente quanto ao controlo de fontes de perigo. Progride-se, assim, para uma paulatina substituição do desvalor do resultado pelo desvalor da acção como critério de ilicitude penal. ${ }^{161}$

"A «sociedade do risco» é a manifestação contemporânea de um fenómeno recorrente, a saber, a procura de uma fundamentação para introduzir na dogmática critérios que venham modificar o princípio da responsabilidade pessoal." ${ }^{162}$ No que diz respeito à fundamentação político criminal e ao objecto da responsabilidade penal, estamos em crer que essa modificação não deverá, pois, acontecer no direito penal do futuro, devendo este manter-se fiel à sua matriz liberal. Um direito penal subsidiário, mínimo e fragmentário, materialmente e teleologicamente legitimado pela preservação axiológica social e orientado para a prevenção.

Direito penal do futuro: um direito de liberdade?

Vimos como o advento do racionalismo humanista trouxe o valor da segurança jurídica do indivíduo face à actuação do Estado, reacção necessária à concepção hobbesiana do poder despótico e absoluto como garante último da paz social. O Estado-de-Direito formal, baseado na legalidade (reserva de lei, tipicidade e irretroactividade) permitiu o afastamento

158 Cfr. Susana AIRES DE SOUSA, Os Crimes Fiscais..., cit., p. 223.

159 Cfr. Hermínio RODRIGUES, op. cit., pp. 50-51.

160 Cfr. Augusto SILVA DIAS, Entre «comes e bebes»: debate de algumas questões polémicas no âmbito da protecção jurídico-penal do consumidor (a propósito do acórdão da Relação de Coimbra de 10 de Julho de 1996), in: RPCC, ano VIII, 1998, n. ${ }^{\circ} 4$ e RPCC, ano 9, 1999, p. 75; Augusto SILVA DIAS, Os crimes de fraude fiscal e de abuso de confiança fiscal: alguns aspectos dogmáticos e político-criminais, in: Ciência e Técnica Fiscal, n. ${ }^{\circ}$ 394, 1999, p. 47.

161 Cfr. Klaus GÜNTHER, De la vulneración de un derecho a la infracción de un deber: un cambio de paradigma en el Derecho Penal?, in: La Insostenible Situación del Derecho Penal, Comares, Granada, 2000, p. 497.

162 Cfr. Maria Margarida SILVA PEREIRA, Direito Penal - Direito do Risco, Comparticipação Crimininosa, Tráfico de Influência, Quid Iuris, Lisboa, 2012 pp. 25-26. 
da legitimação totalitária do Estado. O primado da lei atribuiu garantias ao indivíduo face ao exercício do ius puniendi, garantias reforçadas por uma consagração constitucional formal, mas também material, corolário que são do princípio da dignidade da pessoa humana. Vimos, também, que, na 2. ${ }^{a}$ metade do séc. XXI se aprofundou o humanismo penal, muito influenciado pelo pensamento de FERRAJOLI, tendo a idiossincrasia do "direito penal do cidadão" influenciado o legislador do último quartel do séc. XX.

Todavia, hoje, mais do que nunca, pede-se eficácia ao sistema de justiça penal e erige-se o valor da segurança colectiva a principal incumbência do Estado. Desencadeia-se, assim, um processo de negação e transformação paulatina dos princípios enformadores do Estado de Direito e pede-se ao direito penal que seja, simultaneamente, um «Direito de liberdade», limitador da intervenção estatal sobre a pessoa, e um «Direito de segurança», isto é, um direito compressor dos direitos da pessoa. Pede-se, pois, ao Estado que cumpra duas funções, colocando-o numa situação paradoxal: por um lado, que limite os seus poderes, em nome da protecção dos direitos fundamentais; por outro, que amplie os seus poderes também em favor dos direitos das pessoas.

A eficácia e eficiência do sistema (e a segurança colectiva), por um lado, e a protecção de direitos fundamentais do arguido, por outro, protagonizam uma intensa tensão dialéctica dentro do direito penal ${ }^{163}$, porque tensa é, também, a relação entre os valores da liberdade individual e da segurança. Actualmente, tendência dos Estados e das instâncias supra-estaduais para o reforçar do valor da segurança leva a reequacionar o equilíbrio de forças neste binómio.

A segurança tem o mesmo valor que a liberdade? A dignidade da pessoa humana também fundamentar e legitimar um outro plano da liberdade pessoal, no sentido do livre desenvolvimento da personalidade e realização da pessoa: o direito a fazer uso e fruição das suas liberdades fundamentais em segurança. Este direito à segurança tem acolhimento no acervo normativo supranacional, europeu e internacional, tanto no âmbito do sistema da Organização das Nações Unidas, como no sistema da União Europeia. Como pedra de toque nesta matéria, temos desde logo a Declaração Universal dos Direitos do Homem de 1948, instrumento de soft law, mas que se tornou na principal referência na construção da teoria dos direitos humanos, e consequentemente, dos direitos fundamentais da pessoa. $\mathrm{O}$ art. $3 .^{\circ}$ da DUDH estabelece que "todo o indivíduo tem direito à vida, à liberdade e à segurança pessoal". O art. 9. ${ }^{\circ}$ do Pacto Internacional dos Direitos Civis e Políticos (PIDCP) reza que "Todo o indivíduo tem direito à liberdade e à segurança da sua pessoa...". Também

163 Já, há muitos anos, dizia João BAPTISTA MACHADO (Introdução ao Direito e ao Discurso Legitimador, Almedina, Coimbra, 1995, p. 58): "A exigência de segurança pode, porém, conflituar com a exigência de justiça. Justiça e segurança acham-se numa relação de tensão dialéctica." 
o art. $5 .^{\circ} \mathrm{n} .{ }^{\circ} 1$ da Convenção Europeia sobre os Direitos Humanos (CEDH) diz que "toda a pessoa tem direito à liberdade e à segurança". Já o reconhecimento formal de um catálogo de direitos humanos (de entre eles, o direito à segurança) no âmbito do sistema normativo da União Europeia só aconteceu com a Carta de Direitos Fundamentais da União Europeia de 2001, tendo adquirido força vinculativa em 2007, com o Tratado de Lisboa. O respectivo art. 6. ${ }^{\circ}$ estipula: "Toda a pessoa tem direito à liberdade e à segurança."

No plano constitucional interno, o direito à segurança aparece intimamente associado àqueloutro direito fundamental, a liberdade ${ }^{164}$. O art. 27. ${ }^{\circ}$ da CRP estabelece que "todos têm direito à liberdade e à segurança".

Mas, qual a relação de forças? Qual o interesse preponderante? Autores como ISENSEE contrapõem ao valor da segurança colectiva a ideia da liberdade individual como estatuto positivo indissociável à dignidade da pessoa, o que significa que o direito individual à segurança, elevando-se à categoria de direito fundamental, é, afinal, a própria condição de exercício pleno da liberdade. ${ }^{165}$ Esta concepção parte da ideia de que os direitos fundamentais não podem prescindir de um estatuto positivo que completaria o seu sentido e alcance, acrescendo ao estatuto negativo. Significa, então, que o programa constitucional contém uma vinculação do Estado à promoção das condições para o exercício do direito fundamental à liberdade, que forçosamente contraria, ou, pelo menos, serve de contrapeso, à tendência para a funcionalização do sistema penal ao valor da segurança colectiva. Acresce que o sistema de normas sobre direitos fundamentais deve ser interpretado como não sendo passível de interpretação restritiva, o que favorece a ideia de que aqueles direitos hão-de prevalecer sobre programas penais securitários votados à integridade do sistema. ${ }^{166}$

Por outro lado, Franz KAUFMANN e Niklas LUHMANN apontam ${ }^{167}$ a incapacidade que a intervenção securitária penal tem de controlar os «novos riscos», pois que estes teriam uma capacidade adaptativa crescente, tornando inútil a restrição das liberdades individuais em prol da percepção de segurança colectiva.

Estas ideias apontam para uma clara preponderância da liberdade sobre o interesse da segurança cognitiva. Como nos diz GUEDES VALENTE: "a prossecução da segurança interna e a perseguição criminal não podem ser motivo ou fundamento para um restrição

164 Cfr. Gomes CANOTILHO / Vital MOREIRA, Constituição da República Portuguesa Anotada, vol. I, 4. ${ }^{\mathrm{a}}$ ed., Coimbra Editora, Coimbra, 2007, pp. 478 e 479.

165 Cfr. Maria Margarida SILVA PEREIRA, Direito do Risco..., cit., p. 21.

166 Vide Jorge MIRANDA, Manual de Direito Constitucional, Tomo IV, $3{ }^{\text {a }}$ ed., Coimbra Editora, Coimbra, 2000, pp. 337-341; GOMES CANOTILHO e VITAL MOREIRA, Constituição da República Portuguesa Anotada, Vol. I, 4. ${ }^{\text {a }}$ ed., Coimbra Editora, Coimbra, 2007, pp. 388-396; José Carlos VIEIRA DE ANDRADE, Os Direitos Fundamentais na Constituição Portuguesa de 1976, 3. ${ }^{\mathrm{a}}$ ed., Almedina, Coimbra, 2004, pp. 298-312.

167 Cfr. Maria Margarida SILVA PEREIRA, Op. cit., p. 24. 
desadequada, desnecessária, inexigível, desproporcional stricto sensu, ou para o aniquilamento do conteúdo, do alcance e extensão dos direitos fundamentais, porque estes são, simultaneamente, o seu legado legítimo e o seu limite." 168 Acresce que quaisquer normas destinadas à prevenção e repressão de delitos susceptíveis de contender com direitos fundamentais devem, não só, observar princípios constitucionais e penais, como também gozar, para além da legitimidade normativa, de legitimidade sociológica apoiada na defesa dos valores defendidos pela comunidade. ${ }^{169}$

Não obstante, a tendência para a eleição da segurança colectiva como valor reitor da política criminal tem-se demonstrado mesmo ao nível das Instituições da União Europeia ${ }^{170}$, onde se tem instalado um discurso «belicista», marcado por palavras de ordem como "luta", "combate", "tolerância zero". ${ }^{171}$ Sobre isto, Augusto SILVA DIAS diz-nos, de forma peremptória, que a União Europeia concebe o sistema penal como "um instrumento de política de segurança, sem que a liberdade cidadã seja tida como um contrapeso ou travão à sua expansão."172 No âmbito do projecto europeu de construção do terceiro pilar - um grande espaço de «liberdade, segurança e justiça», muito embora uma harmonização dos ordenamentos jurídico-penais pudesse demonstrar a preocupação com uma aplicação mais igualitária das garantias penais, a verdade é que o grande referente daquele espaço é, nos termos do TFUE (art. 67. ${ }^{\circ}$ ), o valor da segurança, o qual norteia toda a função de protecção das liberdades e direitos fundamentais no espaço europeu. ${ }^{173} \mathrm{Ou}$ seja, a edificação do espaço penal europeu far-se-á sob a égide da segurança como garante da liberdade, no sentido de realizar a justiça, segurança essa operacionalizada por via cooperação penal, em detrimento da harmonização. ${ }^{174}$ Fica, assim, muito debilitada a construção da própria ideia de «cidadania europeia», ao mesmo tempo que se adopta uma atitude belicista de exclusão e coisificação em relação àqueles que perturbarem. Diz-nos Pedro CAEIRO: “(...) até agora, o espaço de liberdade, segurança e justiça tem funcionado, principalmente, no sentido de uma compressão da liberdade, em homenagem à segurança (ou, o que é o mesmo, no sentido da liberdade atra-

168 Manuel M. GUEDES VALENTE, Contributos para um Direito Penal Supranacional, 3. ${ }^{\text {a }}$ ed., Legit, s/l, 2018 , p. 17.

169 Cfr. Manuel M. GUEDES VALENTE, Op. cit., p. 16.

170 Cfr. Pedro CAEIRO, Cooperação Judiciária na União Europeia, in: Direito Penal Económico e Europeu: Textos Doutrinários, Vol. III, Coimbra: Coimbra Editora, 2009, p. 77; Anabela MIRANDA RODRIGUES, O Mandado de Detenção Europeu - Na Via da Construção de um sistema penal europeu: um passo ou um salto?, in: O Direito Penal Europeu Emergente, Coimbra Editora, Coimbra, 2008, p. 219; Idem, A Emergência de um “Direito Penal Europeu" - Questões Urgentes de Política Criminal, in: O Direito Penal Europeu Emergente, Coimbra Editora, Coimbra, 2008, pp. 236-237.

171 Pedro CAEIRO, Cooperação Judiciária na União Europeia..., cit., p. 76; José de FARIA COSTA, A Criminalidade em um Mundo Globalizado..., cit., p. 118.

172 Cfr. Anabela MIRANDA RODRIGUES, O Mandado de Detenção Europeu..., cit., pp. 191 e ss.; Augusto SILVA DIAS, De que Direito Penal Precisamos Nós Europeus? Um olhar sobre algumas propostas recentes de constituição de um direito penal comunitário, in: RPCC, Coimbra Editora, Coimbra, 2004, ano 14, n. ${ }^{\circ}$ 3, p. 318.

173 Cfr. Anabela MIRANDA RODRIGUES, A Emergência de um "Direito Penal Europeu..., cit. p. 228.

174 Cfr. Anabela MIRANDA RODRIGUES, Politica Criminal - Novos Desafios, Velhos Rumos..., cit. p. 173. 
vés do direito penal) e não no sentido inverso (da liberdade contra o direito penal) (...)."175 Particularmente preocupante, nesta matéria, é o facto de a prioridade dada à estratégia do reconhecimento mútuo em detrimento da harmonização legislativa, pode conduzir o legislador das Estados-Membros a pautar os seus respectivos ordenamentos por um nível mínimo essencial de garantias substantiva e processuais, de modo a flexibilizar e agilizar os mecanismos de cooperação policial e judiciária. ${ }^{176}$

Esta edificação de um mega-sistema punitivo de índole securitária demonstra a tendência actual para um claro retorno à noção do "delinquente-inimigo"177, fortemente influenciada pelas concepções criminológicas de GARÓFALO e da Escola Positiva Italiana: o criminoso irrecuperável por tendências inatas e fortemente perturbador da integridade de um espaço comunitário que se quer seguro, o qual há que inocuizar, adoptando-se, para tanto, a via da prevenção por antecipação da tutela penal, inclusive por recurso a indicadores resultantes de um cálculo actuarial, à guisa da política criminal norte-americana. $\mathrm{O}$ resultado final de uma tal política criminal mais não será do que a produção de outsiders, por diabolização daqueles que cometem factos típicos e ilícitos ${ }^{178}$, o que reforçará sempre, mais e mais, a justificação politico-criminal para a implementação de uma qualquer New Penology de inspiração actuarial e securitária, tal como proposto por FREELEY e SIMON. ${ }^{179}$

Um dos grandes desafios que hoje se colocam à legitimação da intervenção penal é, justamente, a identificação precisa dos limites que a Constituição impõe ao uso dos mais variados instrumentos de combate ao crime. O que há-de ser permitido, então, com forma de assegurar condições de efectiva liberdade? A supressão completa da própria liberdade? $\mathrm{O}$ valor da segurança autoriza a sua promoção a qualquer custo, mesmo com claro abuso de mandato social por parte do legislador e das forças de segurança numa espécie de estado-de-excepção, à guisa de SCHMITT? ${ }^{180} \mathrm{O}$ direito penal há-de assentar numa concordância

175 Pedro CAEIRO, Op. cit., p. 77.

176 Cfr. Anabela MIRANDA RODRIGUES, O Mandado de Detenção Europeu..., cit., p. 217-218.

177 Manuel M. GUEDES VALENTE, Direito Penal do Inimigo..., cit., p. 105.

178 Cfr. José de FARIA COSTA, O Fenómeno da Globalização e o Direito Penal Económico, in: Direito Penal Económico e Europeu: Textos Doutrinários, Vol. III, Coimbra: Coimbra Editora, 2009, p. 121; Vide, sobre a teoria dos outsiders, Howard S. BECKER, Outsiders - Estudos de Sociologia Criminal, Zahar, Rio de Janeiro, 2008.

179 Cfr. FREELEY, M./SIMON, J. The New Penology: Notes on the Emerging Strategy of Corrections and its Implications, 30 , Criminology 449, 470 (1992). Vide, ainda, André LAMAS LEITE, Nova penologia, punitive turn e direito criminal: quo vadimus? pelos caminhos da incerteza (pós-)moderna, in: Direito Penal - Fundamentos Dogmáticos e Político-Criminais Homenagem ao Prof. Peter Hünerfeld, Coimbra Editora, Coimbra, 2013, p. 395-476; Bernardo del ROSAL BLASCO, Hacia un Derecho Penal de la Postmodernidad?, in: Revista Electrónica de Ciencia Penal y Criminología, 2009, n. ${ }^{\circ}$ 11-08, p. 8-35; KEMPF-LEONARD / PETERSON, Expanding Realms of the New Penology - The Advent of Actuarial Justice for Juveniles, in: Punishment \& Society, vol. 2, n. ${ }^{\circ} 1$, January 2000, p. 66-97.

180 Vide Carl SCHMITT, Teologia Política, Trotta, Madrid, 2009; Giorgio AGAMBEN, Homo Sacer: O poder soberano e a vida nua, I, UFMG, Belo Horizonte, 2010; Jacques DERRIDA, Força de Lei: O fundamento Mítico da Autoridade, Martins Fontes, São Paulo, 2010. 
prática entre os imperativos político-criminais e o valor da liberdade individual, de modo a que uma correcta ponderação desses interesses possa conduzir a uma intervenção penal em defesa do quadro axiológico constitucional possa, ao mesmo tempo, respeitar o catálogo de direitos fundamentais e, assim, perspectivar a pessoa do agente como pessoa humana. ${ }^{181}$

Os direitos fundamentais são posições jurídicas activas das pessoas integradas no Estado-sociedade, exercidas por contraposição ao Estado-poder, previstas e garantidas pela Constituição, através de uma tutela reforçada. O objectivo próprio dos direitos fundamentais coincide, porque por ele é inspirado, com as finalidades macrossociais dos direitos humanos: exigir das instituições dotadas de prerrogativas de poder público, interno ou internacional, actuação e tratamento condignos com a condição da Humanidade, o que implica que, nomeadamente, o poder do Estado, se abstenha de intromissões desnecessárias e desproporcionais na esfera do indivíduo, devendo perspectivá-lo, na sua essência imutável, como um fim em si mesmo e nunca como um meio de realização de interesses supra-individuais da colectividade. ${ }^{182}$ Isto significa que, no plano constitucional, os direitos fundamentais buscam a sua legitimidade directamente na dignidade da pessoa humana, o que determina que o poder do Estado só pode encarar a pessoa numa perspectiva personalista: nem individualista, como no liberalismo, nem transpersonalista, como nos regimes totalitários. ${ }^{183} \mathrm{~A}$ invalidade e a ilegitimidade das normas infraconstitucionais que não respeitem os direitos fundamentais, positivados ou não, deriva, justamente, do princípio da dignidade da pessoa humana assim interpretado.

Certo é, então, que a preocupação com a máxima eficácia do sistema penal não pode sobrepor-se à dignidade da pessoa humana, materializada nas garantias fundamentais do arguido, como têm defendido vários sectores da doutrina. ${ }^{184} \mathrm{~A}$ "explosão do direito penal omnipresente e omnipotente"185 pode incutir a ideia de uma maior organização social, mas não será capaz de inverter, no futuro, a descrença na eficácia da lei e do aparelho de Estado no controlo da criminalidade e a desconfiança generalizada nas instituições públicas. Isto porque uma concepção do direito penal como "bastão do Estado" capaz de destruir a cri-

181 Cfr. Manuel M. GUEDES VALENTE, Direito Penal do Inimigo..., cit., p. 125. Vide, tb. Manuel M. GUEDES VALENTE, Contributos para um Direito Penal Supranacional..., cit., pp. 30-31; Anabela MIRANDA RODRIGUES, Política Criminal..., cit., pp. 179-181;

182 Cfr. Jorge BACELAR GOUVEIA, Dignidade e Pessoa Humana, in: AAVV. Enciclopédia de Direito e Segurança (Bacelar GOUVEIA/Sofia SANTOS, coord.), Almedina, Coimbra, 2015, p. 112 e ss.

183 Cfr. Jesus González PÉREZ, La Dignidad de la Persona, Civitas, Madrid, 1986, pp. 23 e ss.

184 Cfr. Pedro CAEIRO, Cooperação Judiciária na União Europeia, in: Direito Penal Económico e Europeu: Textos Doutrinários, Vol. III, Coimbra: Coimbra Editora, 2009, pp. 76 e ss; José de FARIA COSTA, O Fenómeno da Globalização e o Direito Penal Económico..., cit., p. 111.

185 Gonçalo N. C. de Melo BANDEIRA, Responsabilidade Penal Económica e Fiscal de Entes Colectivos, Almedina, Coimbra, 2004, p. 36 
minalidade através da repressão violenta e da antecipação da tutela com base na pretensa periculosidade só provocará mais violência. ${ }^{186}$

Uma tal concepção, legitima a intervenção penal do Estado com finalidade de protecção da integridade de si próprio, como se fora um fim em si mesmo, operando-se, assim a completa inversão da própria noção de Estado democrático comprometido com a protecção dos valores do humanismo e fundado, sobretudo, na dignidade da pessoa humana. ${ }^{187}$ Ora, pelo contrário, o fim último do Estado e do seu mandato jus-político é, justamente, a promoção da dignidade da pessoa, o que só é possível através do reconhecimento de que a liberdade é o valor mais alto que preside à realização da justiça. $O$ valor segurança acrescido à justiça são condições do asseguramento da plena liberdade. ${ }^{188}$

Um Estado de Direito Democrático edificado à imagem do Homem, há-de resignar-se à inevitabilidade da insegurança, como condição da sua própria sobrevivência. ${ }^{189} \mathrm{~A}$ antítese entre demanda por segurança e respeito da dignidade da pessoa humana só pode ser resolvida pela (re)afirmação dos direitos fundamentais na definição de uma qualquer política criminal, a qual deve tetralogicamente fundada, como defende FERRAJOLI..$^{190}$

O direito penal do futuro há-de, pois, concretizar o equilíbrio entre a função de protecção da sociedade e dos seus bens jurídicos essenciais e o integral respeito pela pessoa do delinquente face ao aparelho punitivo do Estado, de modo a que a pessoa do infractor seja perspectivada como um fim em si mesmo e nunca como um meio para atingir um certo estádio social ou uma desejada pacificação comunitária, através do uso do direito penal, material e processual como instrumento de segurança. ${ }^{191}$

"A «nova» justiça penal deve assumir o «rosto» da Humanidade"192. Logo, "o Direito penal não é nem deve ser um Direito de necessidade, mas um Direito de liberdade." ${ }^{193}$

\section{CONCLUSÃO}

A percepção dos riscos da globalização e da real ameaça da criminalidade organizada e transnacional (e, em alguns casos, global), bem como pânico gerado pelo fenómeno do

186 Cfr. Idem, ibidem.

187 Cfr. Albin ESER, Una justicia penal «A la medida del ser humano» en la época de la europeización y la globalización, in: Modernas Tendencias en la Ciencia del Derecho Penal y la Criminología, UNED, Madrid, 2001, p. 17

188 Cfr. Mário FERREIRA MONTE, O Direito Penal Europeu de "Roma" a "Lisboa" - Subsidios para a Sua Legitimação, Quid Iuris, Lisboa, 2009, p. 81 e ss.

189 Cfr. Jorge de FIGUEIREDO DIAS, O Direito Penal entre a "Sociedade industrial" e a "Sociedade do Risco", in: Estudos em Homenagem ao Prof. Doutor Rogério Soares, BFDUC, Stvdia Ivridica, n. ${ }^{\circ} 61$, Outubro de 2001, p. 583 e ss.

190 Cfr. Luigi FERRAJOLI, Derecho y Razon, Teoria del Garantismo Penal, 5. a ed., Trotta, Madrid, 2005, pp. 358 - 360.

191 Winfried HASSEMER, História das ideias penais na Alemanha do pós-guerra, AAFDL, Lisboa, 1995, pp. 42-50 e 63-82.

192 Anabela MIRANDA RODRIGUES, Política Criminal..., cit., p. 182.

193 Manuel M. GUEDES VALENTE, Direito Penal do Inimigo..., cit., p. 130. 
terrorismo internacional, incutiu nas sociedades a ideia de que o garantismo penal é um obstáculo à eficácia no controlo desses fenómenos e de que vale a pena sacrificar certas garantias para, assim, afirmar a segurança e a tranquilidade públicas. A noção de que se está perante uma criminogénese sem precedentes, à qual não é alheia a percepção do terrorismo transnacional como nova ameaça global, criou a convicção de que os paradigmas juspenais, materiais e processuais, já não são capazes de dar uma resposta eficaz aos novos desafios.

Por outro lado, o advento da pós-modernidade trouxe consigo grandes e novos riscos e a falência da razão técnica e instrumental calculadora no controlo dos mesmos, o que provocou uma acelerada fuga para o direito penal, convertido, assim, em instrumento de controlo de riscos.

Se, do ponto de vista da sua missão, a direito penal do futuro deve ter na protecção dos bens jurídicos socialmente estruturantes o seu pensar fundamental, a sua teleologia legitimadora, não é menos verdade que tal objectivo não pode ser perseguido à custa da dignidade da pessoa humana e das suas liberdades fundamentais. As teorias funcionalistas, deformalizadoras e securitárias, preconizam o ideal da integridade do sistema e a protecção dos bens jurídicos através de diferentes abordagens face aos diversos tipos de criminalidade: seja criando tipos penais de agente, seja abandonando totalmente a função instrumental-material do direito penal, em favor do seu uso como instrumento de segurança. Ora, é aqui que pensamos que o direito penal do futuro corre sérios riscos de se tornar um direito totalitário e fortemente funcionalizado a proporcionar a simples segurança cognitiva, num processo de total obliteração dos princípios do Estado de Direito democrático.

No que concerne à legitimação teleológica, será o direito penal do futuro um sistema sancionatório perfeitamente funcionalizado à gestão do risco e à prevenção geral positiva integradora? Ou deverá permanecer uma ordem normativa votada à defesa das condições da existência humana? Temos por certo que o direito penal não deverá abandonar o seu carácter instrumental. Nenhum modelo penal deve abandonar o bem jurídico como fundamento o padrão crítico do ilícito, de legeferenda e de jure constituto. Entendemos ser de recusar qualquer proposta que se alicerce numa ideia de funcionalização intensificada do direito penal, que pretenda transformá-lo num instrumento de ordenação social através de uma actuação marcadamente antecipatória na sua tutela: a perseguição penal futura através de medidas de prevenção avançada. ${ }^{194}$

194 Cfr. Manuel M. GUEDES VALENTE, Processo Penal, Segurança e Liberdade: Uma Provocação, Revista Brasileira de Direito Processual Penal, Ano I, n. ${ }^{\circ}$ 1, Janeiro - Junho de 2015, p. 105. Cfr. Hermínio RODRIGUES, op. cit., pp. 56 ess. 
A toda a norma jurídico-penal estão subjacentes juízos de valor sobre condições vitais para a convivência humana em sociedade, que são, por isso, bens que não podem deixar de considerar-se merecedores de protecção através do poder coercivo do Estado, representado pela proibição ínsita nos tipos penais e pelas penas. Muito embora o conceito jurídico-penal, iluminista e fundacional, de bem jurídico tenha, no contexto da «sociedade do risco», necessariamente, outros contornos, nomeadamente uma natureza supra-individual ou colectiva, a sua exclusiva protecção não pode deixar de ser o fim último e o pensar fundamental do direito penal do futuro. Será, ainda e sempre, a concreta ofensividade aos interesses fundamentais da sociedade que ditará a dignidade penal da conduta, permitindo conservar a identidade do direito penal num equilíbrio entre a mínima intervenção e a antecipação da tutela ao limiar do risco. ${ }^{195}$

Um direito penal funcionalmente orientado à protecção dos bens jurídicos fundamentais não pode deixar de ser um direito penal respeitador das liberdades da pessoa e da sua dignidade em geral. O direito penal do futuro haverá de encontrar o seu referente fundamental no quadro axiológico constitucional dos direitos fundamentais de primeira geração, e encontrar na legalidade e na igualdade os pressupostos inspiradores de toda a sua actuação. Uma dogmática penal e processual penal respeitadora da condição humana do agente só pode ser um direito penal votado à preservação, acima de tudo, da vida, da dignidade humana e da liberdade como valores sociais e jurídicos estruturantes.

Se persistirmos na "heurística do medo" de que nos fala Hans JONAS, iremos em direcção à entropia nas relações humanas, à falta de reconhecimento do rosto do outro. Como diz LEVINAS $^{196}$, o ser não é uma totalidade, mas sim um infinito. Ele não acaba em si mesmo, existe em todos os outros na medida da identificação que entre eles existe. O ser só se realiza e define no rosto do outro, e é, precisamente, a partir da face do outro que encontramos o dever que cabe a cada um de nós e nos faz ser verdadeiramente sujeito ${ }^{197}$. E é por isso que o direito penal do futuro não pode deixar de ter "o rosto da humanidade".

\section{BIBLIOGRAFIA}

AGAMBEN, Giorgio. Homo Sacer: O poder soberano e a vida nua, I, UFMG, Belo Horizonte, 2010. AGUADO, Paz de La Cuesta. Causalidad de los delitos contra el medio ambiente, Tirant lo Blanch, Valencia, 1995. AIRES DE SOUSA, Susana. Risco, precaução e responsabilidade no horizonte da incerteza, in: Estudos em Homenagem ao Professor Doutor José Joaquim Gomes Canotilho, BFD, Studia Juridica n. ${ }^{\circ}$ 102, Coimbra Editora, Coimbra, 2012.

195 Cfr. Hermínio RODRIGUES, op. cit., p. 58.

196 Cfr. Emmanuel LEVINAS, Totalidade e Infinito, Edições 70, Lisboa, 1988, p. 266.

197 Cfr. Idem, ibidem. 
ALBRECHT, Peter Alexis. El Derecho Penal en la intervención de la politica populista, in: La Insostenible Situación del Derecho Penal, Comares, Granada, 2000.

ALLER, Germán. El Derecho Penal del Enemigo y La Sociedad de Conflicto, Derecho Penal del Enemigo, Vol. I, MELIÁ; GOMEZ-JARA DIÉZ (coord.), Edisofer, Madrid, 2006.

ALMEIDA, Luís Nunes de. Tolerância, Constituição e Direito Penal, in: Revista Portuguesa de Ciências Criminais, Coimbra Editora, Coimbra, 2013, ano 13, n. ${ }^{\circ} 2$.

AMBOS, Kai. Derecho Penal del Enemigo, in: Derecho Penal del Enemigo, Vol. I, MELIÁ; GOMEZ-JARA DIÉZ (coord.), Edisofer, Madrid, 2006.

ANDERSON, Peter J. Politica Global do Poder, Justiça e Morte, Piaget, Lisboa, 1998.

BACELAR GOUVEIA, Jorge. Direito da Segurança, Almedina, Coimbra, 2018.

, Dignidade e Pessoa Humana, in: AAVV. Enciclopédia de Direito e Segurança (Bacelar GOUVEIA/ Sofia SANTOS, coord.), Almedina, Coimbra, 2015.

BANDEIRA, Gonçalo N. C. de Melo. Responsabilidade Penal Económica e Fiscal de Entes Colectivos, Almedina, Coimbra, 2004.

BAPTISTA MACHADO, João. Introdução ao Direito e ao Discurso Legitimador, Almedina, Coimbra, 1995.

BARBER, Benjamin, Fear's Empire: War, Terrorism and Democracy, W. W. Worton, New York, 2003.

BAUMAN, Zygmunt. Modernidade Líquida, Zahar, Rio de Janeiro, 2001.

BECK, Ulrich. La Sociedad Del Riesgo Global, Siglo XXI de España, Madrid, 2002.

, La Sociedad Del Riesgo Mundial: En busca de la seguridad perdida, Paidós, Barcelona, 2008. La Sociedade del Riesgo. Hacia una Nueva Modernidad, Paidós, 1998.

BECKER, Howard S. Outsiders - Estudos de Sociologia Criminal, Zahar, Rio de Janeiro, 2008.

BOBBIO, Norberto. As Ideologias e o Poder em Crise, $4{ }^{a}$ ed., UNB, Brasília, 1999.

CABRAL DE MONCADA, Luís. Filosofia do Direito e do Estado, Vol. I, Coimbra Editora, Coimbra, 2. ed., 1955.

CAEIRO, Pedro. Cooperação Judiciária na União Europeia, in: Direito Penal Económico e Europeu:Textos Doutrinários, Vol. III, Coimbra: Coimbra Editora, 2009.

Legalidade e oportunidade: a perseguição penal entre o mito da "justiça absoluta" e o fetiche da "gestão eficiente" do sistema, RMP 84, 2000.

CANAS, Vitalino, O Crime de Branqueamento de Capitais - Regime de Prevenção e Repressão, Almedina, Coimbra, 2004.

CANOTILHO, Gomes; MOREIRA, Vital. Constituição da República Portuguesa Anotada, Vol. I, 4. ${ }^{\mathrm{a}}$ ed., Coimbra Editora, Coimbra, 2007.

CANOTILHO, J. J. Gomes. Tomemos a Sério os Direitos Económicos, Sociais e Culturais, BFD, Coimbra, Coimbra Editora, 1988.

CARDOZO POZO, Rodrigo. (Bases de La Politica Criminal e Protección Penal de la Seguridad Vial, Universidad de Salamanca, 2009, 509 f., Tese de Doutoramento.

CHEVALIER, J. J.; GUGHET Y. As Grandes Obras Políticas de Maquiavel à Actualidade, Europa-América, Lisboa, 2004.

CORCOY BISADOLO, Mirentxu. (Delictos de Peligro y Protección de Bienes Jurídico-penales Supraindividuales, Valencia, Tirant lo Blanch, 1999.

COSTA ANDRADE, Manuel da. Consentimento e Acordo em Direito Penal, Coimbra Editora, Coimbra, 1991.

DE MASI, Domenico. A Sociedade Pós-Industrial, 3. ${ }^{\text {a } e d ., ~ S e n a c, ~ S a ̃ o ~ P a u l o, ~} 2000$.

DERRIDA, Jacques. Força de Lei: O fundamento Mítico da Autoridade, Martins Fontes, São Paulo, 2010.

DIAS DUARTE. Branqueamento de Capitais. O Regime do D.L. $15 / 93$ de 22 de Janeiro e a Normativa Internacional, Porto, Universidade Católica, 2002.

DÍEZ RIPOLLÉS, José Luis. De la Sociedad del Riesgo a la Seguridad Ciudadana: Un Debato desenfocado, in: Revista Electrónica de Ciencia Penal y Criminología (RECPC), 07-01, 2005 
El Nuevo Modelo Penal de la Seguridad Ciudadana, in: Revista Electrónica de Ciencia Penal y Criminología (RECPC) 06-03, 2004.

ESER, Albin. Una justicia penal «A la medida del ser humano» en la época de la europeización y la globalización, in: Modernas Tendencias en la Ciencia del Derecho Penal y la Criminología, UNED, Madrid, 2001.

FARIA COSTA, José de. A Criminalidade em um Mundo Globalizado: ou Plaidoyer por um Direito Penal Não Securitário, in: Direito Penal Económico e Europeu - Textos Doutrinários, Vol. III, IDPEE, Coimbra Editora, Coimbra, 2009. , José de. Direito Penal Económico, Quarteto, Coimbra, 2003.

, José de. Ler Beccaria Hoje, in: Cesare BECCARIA, Dos Delitos e das Penas, Fundação Calouste Gulbenkian, Lisboa, 1998.

, José de. O Fenómeno da Globalização e o Direito Penal Económico, BFDUC, Studia Iuridica, n. ${ }^{0} 61$, Coimbra Editora, Coimbra, 2001.

, O Fenómeno da Globalização e o Direito Penal Económico, in: Direito Penal Económico e Europeu - Textos Doutrinários, Vol. III, Coimbra Editora, Coimbra, 2009.

FERRAJOLI, Luigi. Derecho y Razón. Teoria del Garantismo Penal, trad. de P. Ibañez et. al., 5. ${ }^{a}$ edição, Trotta, Madrid, 2005.

, Democracia y Garantismo, Trotta, Madrid, 2008.

FERREIRA MONTE, Mário. Da Protecção Penal do Consumidor. O problema da (des)criminalização do incitamento ao consumo, Coimbra, Almedina, 1996.

, O Direito Penal Europeu de "Roma" a "Lisboa" - Subsídios para a Sua Legitimação, Quid Iuris, Lisboa, 2009.

O Futuro tem Direito Penal? O Direito Penal tem futuro? Apontamento introdutório à obra de Paulo S. FERNANDES, Globalização, "Sociedade de Risco" e o Futuro do Direito Penal, Almedina, Coimbra, 2001.

FIGUEIREDO DIAS, Jorge de. Direito Penal - Parte Geral. Questões Fundamentais. Teoria Geral do Crime, Coimbra Editora, Coimbra, 2004.

,Direito Penal - Parte Geral. Questões Fundamentais. Teoria Geral do Crime, 2. edição, Coimbra Editora, Coimbra, 2007. O Direito Penal entre a "Sociedade industrial" e a "Sociedade do Risco", in: Estudos em Homenagem ao Prof. Doutor Rogério Soares, BFDUC, Stvdia Iuridica, n. ${ }^{\circ} 61$, Outubro de 2001. Temas Básicos da Doutrina Penal, Coimbra Editora, Coimbra, 2001.

FREELEY, M. / SIMON J. Actuarial Justice: The Emerging New Criminal Law, in: Crime and the Risk Society, O’MALLEY (org.) 1998.

FREELEY, M. / SIMON, J. The New Penology: Notes on the Emerging Strategy of Corrections and Its Implications, 30, Criminology 449, 470 (1992).

FREITAS DO AMARAL, Diogo. Do 11 de Setembro à Crise do Iraque, Bertrand, Lisboa, 2003. , História das Ideias Políticas, Almedina, Coimbra, 1999.

GIDDENS, Anthony. As Consequências da Modernidade, Celta, Lisboa, 1992. , O Mundo na Era da Globalização, Editorial Presença, 2000.

GRACIA MARTIN, Luis. Consideraciones Críticas Sobre al Actualmente Denominado Derecho Penal del Enemigo, in: Revista Electrónica de Ciencia Penal y Criminología (RECPC) 07-02, 2005. , El horizonte del finalismo y el derecho penal del enemigo, Tirant Lo Blanch, Valencia, 2005.

GUEDES VALENTE, Manuel M. Contributos para um Direito Penal Supranacional, $3 .{ }^{a}$ ed., Legit, s/l, 2018. , Direito Penal do Inimigo e o Terrorismo, 2. ${ }^{\mathrm{a}}$ ed., Almedina, Coimbra, 2017. , Processo Penal, Segurança e Liberdade: Uma Provocação, Revista Brasileira de Direito Processual Penal, Ano I, n. ${ }^{\circ} 1$, Janeiro - Junho de 2015. 
La Politica Crimina y la Criminología en Nuestros Dia. Una Visión Desde Portugal, in: Derecho Penal y Criminología como Fundamento da la Política Criminal. Estudios en Homenaje al Prof. Alfonso Serrano Gómez, Dickinson, Madrid, 2006.

GÜNTHER, Klaus. De la vulneración de un derecho a la infracción de un deber: un cambio de paradigma en el Derecho Penal?, in: La Insostenible Situación del Derecho Penal, Comares, Granada, 2000.

HASSEMER, Winfried / MUÑOZ CONDE, Francisco. La Responsabilidad por el Producto en Derecho Penal, Tirant lo Blanch, Valencia, 1995.

, Perspectivas del Derecho Penal Futuro, Revista Penal, Universidad de Huelva, 1998.

, História das ideias penais na Alemanha do pós-guerra, AAFDL, Lisboa, 1995.

,A Segurança Pública no Estado de Direito, AAFDL, 1995.

,Contra el abolicionismo: acerca del porqué no se deberia suprimir el derecho penal, RP, n. ${ }^{\circ} 11,2003$.

Crisis y características del moderno derecho penal. Actualidad Penal, $n^{\circ}$ 43/22, Madrid, 1993.

Lineamentos de una teoría personal del bien jurídico, DP, Año 12, 1989.

Persona, mundo y responsabilidad. Bases para una teoría de la imputación en Derecho Penal, trad. de F.

Muñoz Conde y M.M. Díaz Pita, Tirant lo Blanch, Valencia, 1999.

HEFENDEHL, Roland. Debe Ocuparse El Derecho Penal de Riesgos Futuros? Bienes Jurídicos Colectivos y Delictos de Peligro Abstracto, in: Anales de Derecho, n. ${ }^{\circ} 19$, Universidad de Murcia, 2001.

HERZOG, Felix. Limites del Derecho Penal para controlar los riesgos sociales, in: Poder Judicial n. ${ }^{\circ}$ 32, 1993.

JAKOBS Günther; CANCIO MELIÁ, Manuel. Derecho Penal del Enemigo, Cuadernos Civitas, Madrid, 2003.

La Ciencia Penal ante los Retos del Futuro, in: Albin ESER / Winfried HASSEMER / Björn

BURKHARDT, La ciencia del Derecho Penal ante el cambio de Milenio, Trad. de Teresa MANZO, Francisco MUÑOZ CONDE (Coord.), Valencia, 2004.

, Sobre la Normativización de la Dogmática Jurídico-Penal, trad. CANCIO MELIÁ / FEIJÓO SANCHÉZ, Thomson-Civitas, Madrid, 2003.

INNERARITY, Daniel. A Sociedade Invisivel, Teorema, Lisboa, 2009.

JESCHECK, Hans. Tratado de Derecho Penal, Barcelona, Bosch, 1981.

JONAS, Hans. El principio de responsabilidad: ensayo de una ética para la civilización tecnológica, Herder, Barcelona, 1995.

KANT, Emmanuel. A Paz Perpétua e outros Opúsculos, trad. Artur Mourão, Edições 70, Lisboa, 1989.

KAUFMANN, Arthur. Filosofia do Direito, 5. . ed., Fundação Calouste Gulbenkian, Lisboa, 2014.

KEMPF-LEONARD / PETERSON, Expanding Realms of the New Penology - The Advent of Actuarial Justice for Juveniles, in: Punishment \& Society, vol. 2, n. ${ }^{0} 1$, January 2000.

LAMAS LEITE, André. Nova penologia, punitive turn e direito criminal: quo vadimus? Pelos caminhos da incerteza (pós-)moderna, in: Direito Penal - Fundamentos Dogmáticos e Politico-Criminais - Homenagem ao Prof. Peter Hünerfeld, Coimbra Editora, Coimbra, 2013.

, André. Nueva Penologia, Punitive Turn y Derecho Penal: Quo Vadimus? Por la Incertidumbre (Pos) Moderna, in: InDret - Revista para el analisis del Derecho, nr. 2, Barcelona, 2013.

LEVINAS, Emmanuel. Totalidade e Infinito, Edições 70, Lisboa, 1988.

LÓPEZ CALERA, Nicolás Maria. Hay derechos colectivos? Individualidad y socialidade en la teoria de los derechos colectivos, Barcelona, Ariel, 2000.

LUCAS PIRES, Francisco. Introdução ao Direito Constitucional Europeu, Almedina, Coimbra, 1997.

LUHMANN, Niklas, Risk: A Sociological Theory, Walter De Gruyter, Berlin-New York, 1993.

MAILLARD, Jean de, Crimes e Leis, Piaget, Lisboa, 1995.

MANTOVANI, Fernando. Diritto Penale, Pádova, CEDAM, 2001.

,Fernando. Princípio di ofensivitá tra dogmatica e politica criminale, in: Il Diritto Penale alla Svolta di Fine Millenio, G. Giappichelli Editore, Torino, 1998. 
MARINUCCI / DOLCINNI, Diritto penale minimo e nuove forme de criminalitá, Rivista Italiana di Diritto e procedura penale, 1999

MÁRTINEZ-BUJAN PEREZ, Carlos. Derecho Penal Económico - Parte General, Tirant lo Blanch, Valencia, 1998.

MATA Y MARTÍN, Ricardo M. Bienes jurídicos intermedios y delitos de peligro: aproximación a los presupuestos de la técnica de peligro para los delitos que protegen bienes jurídicos intermedios, Comares, Granada, 1997.

MIR PUIG, Santiago. Bases constitucionales del Derecho penal, Marcial Pons, Madrid, 2011.

MIRANDA RODRIGUES, Anabela. Criminalidade Organizada - Que Política Criminal?, in: Direito Penal Económico e Europeu - Textos Doutrinários, III vol., IDPEE, Coimbra Editora, Coimbra, 2009, p. 187.

Política Criminal - Novos Desafios, Velhos Rumos, in: Direito Penal Económico e Europeu - Textos Doutrinários, III vol., IDPEE, Coimbra Editora, Coimbra, 2009.

Política Criminal - Novos Desafios, Velhos Rumos, in: Liber Discipulorum para Figueiredo Dias, Coimbra Editora, Coimbra, 2003.

, O Mandado de Detenção Europeu - Na Via da Construção de um sistema penal europeu: um passo ou um salto?, in: O Direito Penal Europeu Emergente, Coimbra Editora, Coimbra, 2008.

A Emergência de um "Direito Penal Europeu" - Questões Urgentes de Política Criminal, in: O Direito Penal Europeu Emergente, Coimbra Editora, Coimbra, 2008.

MIRANDA, Jorge. Manual de Direito Constitucional, Tomo IV, 3. ${ }^{\text {a }}$ ed., Coimbra Editora, Coimbra, 2000.

MOCCIA, Sergio. De la tutela de bienes a la tutela de funciones: entre ilusiones postmodernas y reflujos iliberales, in: Política Criminal y Nuevo Derecho Penal (libro homenaje a Claus Roxin), Bosch, Barcelona, 1997.

MOTAPINTO, Paulo. Nota sobreo 'imperativo da tolerância' eseus limites, in: Estudos em Memória do Conselheiro Luís Nunes de Almeida, Coimbra Editora, Coimbra, 2007.

MUÑOZ CONDE, Francisco. El nuevo Derecho penal autoritario, in: El Derecho ante la globalización y el terrorismo, AA. VV., Tirant lo Blanch, Valencia, 2004.

, El nuevo Derecho penal autoritario: consideraciones sobre el llamado Derecho penal del enemigo, in: Mutaciones de Leviatán. Legitimación de los nuevos modelos penales, AA. VV., Akal, Madrid, 2005.

Protección de Bienes Jurídicos como Limite Constitucional al Derecho Penal, Quintero Olivares I

Morales Prats (Coords.). El Nuevo Derecho Penal Español Estudios Penales en Memoria del Profesor José Manuel Valle Muñiz, Editorial Aranzadi, Madrid, 2001.

Protección de Bienes Jurídicos como Limite Constitucional al Derecho Penal, Quintero Olivares I Morales Prats (Coords.). El Nuevo Derecho Penal Español Estudios Penales en Memoria del Profesor José Manuel Valle Muñiz, Editorial Aranzadi, Madrid, 2001.

OST, François. O Tempo do Direito, Piaget, Lisboa, 2001.

NAUCKE, Wolfgang. La progressiva pérdida de contenido del princípio de legalidade penal como consecuencia de um positivismo relativista y politizado, in: La Insostenible Situación del Derecho Penal, Comares, Granada, 1993.

PERELMAN, Chäim. Ética e Direito, Piaget, Lisboa, 2002.

PÉREZ, Jesus González. La Dignidad de la Persona, Civitas, Madrid, 1986.

POLAINO-ORTS, Miguel. Derecho Penal del Enemigo. Fundamentos, Potencial de Sentido y Limites de Vigencia, Bosch, Barcelona, 2009.

PRITTWITZ, Cornelius. El Derecho Penal Alemán: ¿fragmentario? ¿subsidiario? ¿ultima ratio? Reflexiones sobre la razón y límites de los principios limitadores del Derecho penal", in: La insostenible situación del Derecho penal, AA. VV., trad. Maria Teresa Castiñeira Palou, Granada, Comares, 2000.

o Direito Penal entre o Direito Penal do Risco e o Direito Penal do Inimigo: Tendências Actuais em Direito Penale Politica Criminal, in: Revista Brasileira de Ciências Criminais, São Paulo, Revista dos Tribunais - n. ${ }^{\circ} 47$, IBCCRIM, Mar/Abr. 2004. 
, Sociedad del Riesgo y Derecho Penal, in: ARROYO ZAPATERO / NEUMANN / NIETO MARTÍN, Crítica y justificación del Derecho penal en el cambio de siglo. El análisis crítico de la Escuela de Frankfurt, Universidad de Castilla-La Mancha, Cuenca, 2003.

PUREZA, José Manuel. O Património Comum da Humanidade - Rumo a um Direito Internacional da Solidariedade, Afrontamento, Lisboa, 1998.

RODRIGUES, Hermínio C. S., Responsabilidade Penal de Pessoas Colectivas: Uma Revisitação à Luz da Teoria do Risco. Lisboa: Universidade Autónoma de Lisboa, 2016, 122 p. Dissertação de Mestrado (polic.)

ROSAL BLASCO, Bernardo del. Hacia un Derecho Penal de la Postmodernidad?, in: Revista Electrónica de Ciencia Penal y Criminología, 2009, n. ${ }^{\circ} 11-08$.

ROXIN, Claus. ¿Es la protección de bienes jurídicos una finalidad del Derecho penal?, in: Roland HEFENDEHL, (Ed.), La teoría del bien jurídico: ¿Fundamento de legitimación del Derecho penal o juego de abalorios dogmático? Marcial Pons, Madrid, 2007.

Derecho Penal, trad. Luzón Peña, Garcia Conledo, Vicente Remesal, Civitas, Madrid, reimp. 2000. Derecho Penal. Parte General. Tomo I. Fundamentos. La estructura de la Teoría del Delito, Traducción de LUZÓN-PEÑA; García CONLLEDO; Vicente REMESAL, Civitas, Madrid, 1997.

SCHMITT, Carl. Teologia Política, Trotta, Madrid, 2009.

SCHNEIDER, Hans. Recientes investigaciones criminológicas sobre la criminalidad organizada", in: Revista de Derecho Penal y Criminologia, 3, 1993.

SCHÜNEMANN, Bernd. Consideraciones críticas sobre la situación espiritual de la ciencia jurídico-penal alemana, in: Annuario de Derecho Penal y Ciencias Penales, n. ${ }^{\circ}$ 49, fasc. 1, Jan. - Abril, San Bernardo, Madrid, 1996.

El principio de protección de bienes jurídicos como punto de fuga de los limites constitucionales de los tipos penales $y$ de su interpretación, in: Roland HEFENDEHL, (Ed.). La teoria del bien jurídico: ¿Fundamento de legitimación del Derecho penal o juego de abalorios dogmático?, Marcial Pons, Madrid, 2007.

SCHULZ, Lorenz. De la aceleración de las condiciones de vida, in: La Insostenible Situación del Derecho Penal, Comares, Granada, 1999.

SERRA DE CARVALHO, Hamilton. Estado Forte - Hobbesianismo e Maquiavelismo na Ordem Político-Constitucional Global, Chiado Editora, Lisboa, 2016.

SILVA DIAS, Augusto. De que Direito Penal Precisamos Nós Europeus? Um olhar sobre algumas propostas recentes de constituição de um direito penal comunitário, in: RPCC, Coimbra Editora, Coimbra, 2004, ano 14, n. ${ }^{\circ} 3$. , Delicta in se e delicta mere prohibita: uma análise das descontinuidades do ilícito penal moderno à luz da reconstrução de uma distinção clássica, FDUL Lisboa, 2003.

Entre «comes e bebes»: debate de algumas questões polémicas no âmbito da protecção jurídico-penal do consumidor (a propósito do acórdão da Relação de Coimbra de 10 de Julho de 1996), in: RPCC, ano VIII, 1998, n. ${ }^{\circ} 4$ e RPCC, ano 9, 1999.

Os crimes de fraude fiscal e de abuso de confiança fiscal: alguns aspectos dogmáticos e politico-criminais, in: Ciência e Técnica Fiscal, n. ${ }^{\circ}$ 394, 1999.

Proteç̧ão Jurídico-Penal do Interesses dos Consumidores, $3 .^{\mathrm{a}}$ ed. policop., FDUC - IDPEE, Coimbra, 2001.

SILVA FRANCO, A. Globalização e Criminalidade dos Poderosos, RPCC, Ano 10 - Fasc. 2. ${ }^{\circ}$, Abril - Junho de 2000.

SILVA PEREIRA, Maria Margarida. Direito Penal - Direito do Risco, Comparticipação Crimininosa, Tráfico de Influência, Quid Iuris, Lisboa, 2012.

SILVA-SÁNCHEZ, Jesús Maria. La Expansión del Derecho Penal. Aspectos de la Politica Criminal en las Sociedades Postindustriales, Civitas, Madrid, 1999.

STELLA, Federico. Giustizia e Modernitá. La Protezione dell' Inoccente e la Tutela delle Vittime, Giuffre Editore, Milano, 2002. 
TAVARES, Juarez. A Globalização e os Problemas de Segurança Pública, in: Revista da Associação Brasileira de Professores de Ciências Penais, São Paulo, ano 1, n..$^{\circ}$ 00, 2004.

TIEDEMANN, Klaus. Lecciones de Derecho Penal Económico, PPU, Barcelona, 1993.

TORRAINE, Alain. Crítica da Modernidade, Piaget, Lisboa, 1994.

VIEIRA DE ANDRADE, José Carlos. Os Direitos Fundamentais na Constituição Portuguesa de 1976, 3. . ed., Almedina, Coimbra, 2004.

ZÚÑIGA RODRIGUEZ, Laura. Política Criminal, Colex, Madrid, 2001.

ZUÑIGA RODRIGUEZ, Laura. Redes Internacionales y Criminalidad: a Propósito del Modelo de Participación en Organización Criminal, in: El Derecho Penal Ante La Globalización, ZUÑIGA RODRIGUEZ, Laura / MENDEZ RODRIGUEZ, Cristina / DÍAZ-SANTOS, M. Rosario (coords.), Colex, Madrid, 2002. 
